\title{
Eddy covariance flux measurements of ammonia by high temperature chemical ionisation mass spectrometry
}

\author{
J. Sintermann ${ }^{1}$, C. Spirig ${ }^{1, *}$, A. Jordan ${ }^{2}$, U. Kuhn ${ }^{1, * *}$, C. Ammann ${ }^{1}$, and A. Neftel ${ }^{1}$ \\ ${ }^{1}$ Swiss Federal Research Station Agroscope Reckenholz-Tänikon ART - Air Pollution and Climate, Zürich, Switzerland \\ ${ }^{2}$ Ionicon Analytik GmbH, Innsbruck, Austria \\ *now at: Swiss Federal Office of Meteorology and Climatology MeteoSwiss, Zürich, Switzerland \\ ** now at: Institut für Energie und Klimaforschung - Troposphäre (IEK-8), Forschungszentrum Jülich, Jülich, Germany
}

Received: 14 October 2010 - Published in Atmos. Meas. Tech. Discuss.: 3 November 2010

Revised: 16 March 2011 - Accepted: 18 March 2011 - Published: 24 March 2011

\begin{abstract}
A system for fast ammonia $\left(\mathrm{NH}_{3}\right)$ measurements with chemical ionisation mass spectrometry (CIMS) based on a commercial Proton Transfer Reaction-Mass Spectrometer (PTR-MS) is presented. It uses electron transfer reaction as ionisation pathway and features a drift tube of polyetheretherketone (PEEK) and silica-coated steel. Heating the instrumental inlet and the drift tube to $180^{\circ} \mathrm{C}$ enabled an effective time resolution of $\sim 1 \mathrm{~s}$ and made it possible to apply the instrument for eddy covariance (EC) measurements. EC fluxes of $\mathrm{NH}_{3}$ were measured over two agricultural fields in Oensingen, Switzerland, following fertilisations with cattle slurry. Air was aspirated close to a sonic anemometer at a flow of $100 \mathrm{STPL} \mathrm{min}^{-1}$ and was directed through a $23 \mathrm{~m}$ long $1 / 2$ " PFA tube heated to $150^{\circ} \mathrm{C}$ to an airconditioned trailer where the gas was sub-sampled from the large bypass stream. This setup minimised damping of fast $\mathrm{NH}_{3}$ concentration changes between the sampling point and the actual measurement. High-frequency attenuation loss of the $\mathrm{NH}_{3}$ fluxes of 20 to $40 \%$ was quantified and corrected for using an empirical ogive method. The instrumental $\mathrm{NH}_{3}$ background signal showed a minor interference with $\mathrm{H}_{2} \mathrm{O}$ which was characterised in the laboratory. The resulting correction of the $\mathrm{NH}_{3}$ flux after slurry spreading was less than $1 \%$. The flux detection limit of the EC system was about $5 \mathrm{ng} \mathrm{m}^{-2} \mathrm{~s}^{-1}$ while the accuracy of individual flux measurements was estimated $16 \%$ for the high-flux regime during these experiments. The $\mathrm{NH}_{3}$ emissions after broad spreading of the slurry showed an initial maximum of $150 \mu \mathrm{g} \mathrm{m}^{-2} \mathrm{~s}^{-1}$ with a fast decline in the following hours.
\end{abstract}

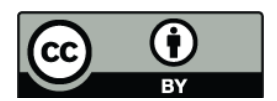

Correspondence to: J. Sintermann (joerg.sintermann@art.admin.ch)

\section{Introduction}

Ammonia $\left(\mathrm{NH}_{3}\right)$ is one of the least understood compounds among the important components in today's terrestrial nitrogen cycle. It accounts for a major proportion of environmentally harmful effects of high nitrogen loads (Erisman et al., 2007). It is the most abundant alkaline trace gas and thus very important for neutralising atmospheric acids like sulphuric or nitric acid. In such, it forms particulate matter (Baek et al., 2004; Smith et al., 2005; Seinfeld and Pandis, 2006; Ortega et al., 2008; Nemitz et al., 2009), therefore contributing to radiative forcing (IPCC, 2007; Shindell et al., 2009) and impacting human health (Pope et al., 2002; Gutierrez, 2010). Populated areas, mainly in Europe, North- and South America and also in parts of Asia experience a large excess of $\mathrm{NH}_{3}$, primarily for reasons of intensified agricultural production (Sutton et al., 2008). The excessive nitrogen input in sensitive ecosystems can result in eutrophication, loss of biodiversity and soil acidification (Galloway et al., 2003). On a global scale, $\mathrm{NH}_{3}$ emissions will most likely increase in future and large uncertainties remain both in the sources and the fate of atmospheric $\mathrm{NH}_{3}$ (Erisman et al., 2007). Agriculture is by far the most dominant contributor to anthropogenic $\mathrm{NH}_{3}$ emissions. In central Europe it is responsible for about $90 \%$ of the $\mathrm{NH}_{3}$ release (Erisman et al., 2008), the same holds for Switzerland (Reidy et al., 2008).

Ambient $\mathrm{NH}_{3}$ mixing ratios range from less than one ppb in remote areas (Sutton et al., 1993b) to levels close to, or exceeding one ppm near strong sources (Flechard et al., 2010). Accurate measurements of $\mathrm{NH}_{3}$ concentrations with a high time resolution (in the order of one minute or faster) are generally difficult due to the stickiness of the polar $\mathrm{NH}_{3}$ molecule to all surfaces (Parrish and Fehsenfeld,

Published by Copernicus Publications on behalf of the European Geosciences Union. 
2000). Additionally, the partitioning between gaseous $\mathrm{NH}_{3}$ and particulate $\mathrm{NH}_{4}^{+}$often complicates the interpretation of the measurements (Parrish and Fehsenfeld, 2000; Nemitz et al., 2004b; Wolff et al., 2010b). One consequence of these measurement challenges is that considerable uncertainties persist in the understanding of the processes controlling emissions and distribution of $\mathrm{NH}_{3}$. For example, knowing the mechanisms controlling $\mathrm{NH}_{3}$ volatilisation after application of organic fertiliser is important to quantify emission strengths and to optimise mitigation strategies. It remains vital to improve the methodology for precise $\mathrm{NH}_{3}$ measurements with a high time resolution for better assessing highly dynamic $\mathrm{NH}_{3}$ fluxes on the field scale $\left(10^{3}\right.$ to $10^{5} \mathrm{~m}^{2}$ ) (Sutton et al., 2007; Fowler et al., 2009).

To date, reported field scale assessments of $\mathrm{NH}_{3}$ fluxes rely on the aerodynamic gradient method (Baldocchi et al., 1988; Sutton et al., 1993a), mostly by means of $\mathrm{NH}_{3}$ analysers that are based on wet chemical analysis which is very labour intensive (Flechard and Fowler, 1998; Erisman et al., 2001; Mosquera et al., 2001; Nemitz et al., 2004a; Wichink Kruit et al., 2007; Flechard et al., 2010; Spirig et al., 2010; Wolff et al., 2010a). The challenging nature of the $\mathrm{NH}_{3}$ flux measurements is also reflected in the results of a recent intercomparison exercise where considerable differences were found (Milford et al., 2009). In order to overcome some of the uncertainties inherent in these measurements, direct flux measurements using the eddy covariance (EC) technique are highly desirable (Sutton et al., 2007; Fowler et al., 2009). It is considered to be the most direct and least error-prone approach (Ammann, 1999; Sutton et al., 2007; Denmead, 2008), but requires the trace gas analyser to resolve the major part of the turbulent spectrum, ranging from frequencies of about 10 to $0.001 \mathrm{~Hz}$ (Businger and Delany, 1990).

Only recently, several sensitive and fast responding instruments for $\mathrm{NH}_{3}$ became available that theoretically opened the possibility to perform EC flux measurements. These are mostly based on principles of chemical ionisation (Shaw et al., 1998; Španěl and Smith, 1998; Fehsenfeld et al., 2002; de Gouw and Warneke, 2006; Nowak et al., 2006; Norman et al., 2007) and absorption of light in the mid-infrared (Edwards et al., 1994; Berden et al., 2000; McManus et al., 2008). Shaw et al. (1998) presented first trials to employ Chemical Ionisation Mass Spectrometry (CIMS) for EC fluxes of $\mathrm{NH}_{3}$. Famulari et al. (2004) performed $\mathrm{NH}_{3} \mathrm{EC}$ measurements by means of Tunable Diode Laser Absorption Spectrometry (TDLAS). In the following, Whitehead et al. (2008) intercompared two fast optical systems (TDLAS and Quantum Cascade Laser Absorption Spectrometer, QCLAS) in EC configuration to determine $\mathrm{NH}_{3}$ fluxes associated with slurry spreading and tested these against the AMANDA wet chemistry gradient system. They found a systematic underestimation of the EC fluxes of $47 \%$, which they could not correct for nor explain.

The difficulties in $\mathrm{NH}_{3}$ measurements primarily have to be attributed to adsorption and re-evaporation of $\mathrm{NH}_{3}$ in filters, inlet tubes and instruments themselves (Parrish and Fehsenfeld, 2000; Fehsenfeld et al., 2002; Schwab et al., 2007). This leads to attenuation of concentration changes and thus most severely limits the application of the EC technique for $\mathrm{NH}_{3}$. Brodeur et al. (2008) evaluated a TDLAS, including inlet lines for $\mathrm{NH}_{3} \mathrm{EC}$ measurements. In the laboratory, they proved the setup to highly underestimate fluxes in most potential measurement situations due to attenuation of fast $\mathrm{NH}_{3}$ fluctuations in the inlet tube. In field applications, the majority of instruments require an inlet tube of several metres length. This attenuates fast concentration changes (Lenschow and Raupach, 1991; Brodeur et al., 2008; Massmann and Ibrom, 2008; Whitehead et al., 2008) and may even introduce severe $\mathrm{NH}_{3}$ concentration alteration in special situations, e.g. during periods of condensation inside the tube (Norman et al., 2009) and $\mathrm{NH}_{3}$ evaporation from the tube walls induced by drying of the inner surface (Hensen et al., 2009; Ellis et al., 2010).

Among the CIMS techniques, Proton Transfer ReactionMass Spectrometry (PTR-MS) is fast enough to be applied with EC (Karl et al., 2001; Jost et al., 2003; Mikoviny et al., 2010), as documented by EC flux measurements of volatile organic compounds (VOCs) (Rinne et al., 2001; Karl et al., 2002, 2004; Spirig et al., 2005; Yokelson et al., 2007; Bamberger et al., 2010). Norman et al. (2007) published a CIMS approach to measure $\mathrm{NH}_{3}$ with a modified commercial PTRMS from Ionicon Analytik GmbH (Innsbruck, Austria), using chemical ionisation of the analyte via electron transfer instead of proton transfer. The instrument reliably measured $\mathrm{NH}_{3}$ concentrations (Norman et al., 2009), but had a response time too slow for EC measurements. To a major part, adsorption and desorption of $\mathrm{NH}_{3}$ on surfaces inside the instrument restricted the time resolution.

In the meantime a new smaller drift tube made of inert materials became available that can be heated up to $200^{\circ} \mathrm{C}$.

In this study, we explore whether the new materials and heating enhance the instrumental time resolution and report on the application of this high temperature CIMS technique (henceforth denominated as HT-CIMS) for EC flux measurements of $\mathrm{NH}_{3}$ after organic fertiliser application. The conditions in the field are best suited to test the applicability of the system for EC measurements as they provide the entire range of turbulent structures in the atmospheric surface layer with corresponding concentration changes that could be simulated only with a very complex laboratory experiment (e.g. Brodeur et al., 2008). The performance of our setup was tested during two slurry applications on an arable and a grassland field. 
Table 1. Comparison of the PTR-MS equipped with conventional (PTR-MS HS2 of Ionicon Analytik) drift tube and HT-CIMS with new prototype drift tube and inlet design.

\begin{tabular}{|c|c|c|}
\hline & conventional & new prototype \\
\hline $\begin{array}{l}\text { drift tube volume } \\
\text { drift tube residence time } \\
\text { drift tube materials }\end{array}$ & $\begin{array}{l}18 \mathrm{~cm}^{3} \\
80 \mathrm{~ms} \\
\text { stainless steel, Teflon }{ }^{\circledR} \text { (PTFE) }\end{array}$ & $\begin{array}{l}7 \mathrm{~cm}^{3} \\
30 \mathrm{~ms} \\
\text { stainless steel coated with } \\
\text { Siltek }^{\circledR} \text { (Restek, Inc., } \\
\text { Bellefonte, PA, USA), PEEK } \\
\text { (polyetheretherketone) }\end{array}$ \\
\hline $\begin{array}{l}\text { drift tube operating } \\
\text { temperature }\end{array}$ & $40-120^{\circ} \mathrm{C}$ & $40-200^{\circ} \mathrm{C}$ \\
\hline instrumental inlet design & $\begin{array}{l}\text { Silcosteel }^{\circledR} \text { (Restek, Inc., } \\
\text { Bellefonte, PA, USA); } \\
\text { capillaries: } 0.25 \& 1 \mathrm{~mm} \text { ID } \\
\text { inlet residence time: } 120 \mathrm{~ms}\end{array}$ & $\begin{array}{l}\text { PEEK; capillaries: } 0.2 \mathrm{~mm} \text { ID, } \\
\text { inlet residence time: } 90 \mathrm{~ms}\end{array}$ \\
\hline
\end{tabular}

\section{Methods}

\subsection{Instrumental}

\subsubsection{Detection of $\mathrm{NH}_{3}$}

PTR-MS (Hansel et al., 1995; Lindinger et al., 1998) is a widely used state-of-the-art CIMS technique, primarily applied to detect VOCs on-line with a high sensitivity and time resolution (de Gouw and Warneke, 2006; Blake et al., 2009). A source gas (water vapour) is protonated inside a hollow cathode and subsequently interacts with the sample gas and transfers protons to components with sufficient proton affinity. The resulting product ions are separated by a quadrupole and afterwards detected with an electron multiplier pulse counter. In recent studies, PTR-MS has been employed to quantify EC fluxes of selected biogenic VOCs (Rinne et al., 2001; Karl et al., 2002, 2004; Spirig et al., 2005; Yokelson et al., 2007). Expanding the field of applications, the PTRMS instrument has been adopted for measurements of ambient $\mathrm{NH}_{3}$ concentrations (Norman et al., 2007, 2009). For this purpose, it is operated with pure oxygen as source gas. The main primary ion resulting from the hollow cathode discharge is charged oxygen $\left(\mathrm{O}_{2}^{+}\right)$. Correspondingly, the main reactions in the drift tube are no longer proton, but electron transfers. In the case of $\mathrm{NH}_{3}$, the resulting product ion is $\mathrm{NH}_{3}^{+}$(Eq. 1), detected as $m / z, 17$ (Španěl and Smith, 1998).

$\mathrm{O}_{2}^{+}+\mathrm{NH}_{3} \rightarrow \mathrm{NH}_{3}^{+}+\mathrm{O}_{2}$.

A detailed description of the ionisation detection scheme, the selectivity and sensitivity of the PTR-MS with electron transfer reactions for $\mathrm{NH}_{3}$ detection is given in Norman et al. (2007). In particular, they found a sensitivity for $\mathrm{NH}_{3}$ of more than $40 \mathrm{cps}$ (counts per second) per ppb of $\mathrm{NH}_{3}$, which is comparable to values typically obtained for PTR-MS measurements of VOCs (Karl et al., 2002; Ammann et al., 2004;
Spirig et al., 2005). In contrast to VOC measurements, where time resolutions in the order of a few $\mathrm{Hz}$ are possible, the response time was much slower with $\mathrm{NH}_{3}$ (Norman et al., 2007). The most probable reason for the slow time constants was a strong damping at the inner surfaces of the instrument due to the high affinity of $\mathrm{NH}_{3}$ to almost any kind of material.

\subsubsection{Instrumental modifications}

In the meantime a new prototype drift tube has been developed by the manufacturer of PTR-MS (Ionicon Analytik $\mathrm{GmbH}$, Innsbruck, Austria). The new design features a smaller volume resulting in a faster gas exchange time and allows heating up to $200^{\circ} \mathrm{C}$. In addition, the fraction of metal at the inner surface was significantly reduced compared to the conventional drift tube. Table 1 summarises the differences between the new prototype and the conventional drift tube. In the following, we will refer to the instrument as applied in the present study as HT-CIMS.

The new HT-CIMS sample inlet consists of PEEK capillaries (Fig. 1) and was optimised for minimum residence time of the air to be analysed. The drift tube samples $\sim 0.022 \mathrm{STPL} \mathrm{min}^{-1}$ through a critical orifice whereas the inlet tubes can be purged with up to $1.1 \mathrm{STPL} \mathrm{min}^{-1}$. The inlet manifold and the drift tube are placed inside an aluminium block equipped with a heater ensuring equal temperatures of all elements. We operated the HT-CIMS drift tube at a voltage of $400 \mathrm{~V}$, a pressure of $2.13 \mathrm{mbar}$ and a temperature of $180^{\circ} \mathrm{C}$ resulting in a ratio of the electrical field to the gas number density $E / N \approx 124 \mathrm{Td}\left(1 \mathrm{Td}=10^{-17} \mathrm{~V} \mathrm{~cm}^{2}\right)$. According to Norman et al. (2007) an $E / N$ close to or below $120 \mathrm{Td}$ may prevent from secondary reactions of $\mathrm{NH}_{3}^{+}$with $\mathrm{H}_{2} \mathrm{O}$. 


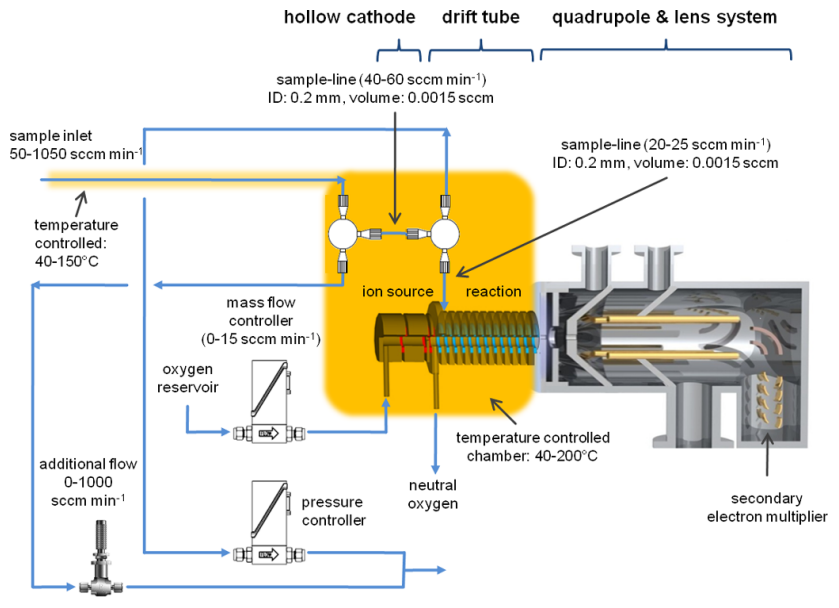

Fig. 1. Scheme of the HT-CIMS including instrumental sample inlet.

\subsubsection{Characterisation and calibration}

Norman et al. (2007) demonstrated the linearity of their instrument over a wide range of $\mathrm{NH}_{3}$ concentrations. They found the instrumental sensitivity for $\mathrm{NH}_{3}$ to be independent from sample humidity, but identified a minor offset linearly depending on water vapour concentration. We performed laboratory experiments to determine the water vapour interference in our instrument. Humid zero air was produced by using compressed synthetic air and guiding it sequentially through two impingers controlled by a mass flow controller: the first impinger contained $\mathrm{HCl}$ solution $\left(0.1 \mathrm{ML}^{-1}\right)$ to eliminate residues of $\mathrm{NH}_{3}$, the second was filled with demineralised water. Both were placed inside a water bath allowing to regulate air humidity via changing the bath temperature. The water was cooled down with ice cubes and subsequently warmed up to room temperature creating a wide range of humidities. Entirely dry zero air was achieved by directing the same synthetic air without impingers through a citric acid coated dry denuder. The HT-CIMS sampled out of an overflow. The overflow air humidity was monitored by a dew point mirror. Experiments with this setup allowed to analyse influences of varying humidity on the instrumental background and also revealed that HT-CIMS can measure water vapour, detected as $\mathrm{m} / \mathrm{z}, 37$ (clustered water molecules $\mathrm{H}_{2} \mathrm{O} \cdot \mathrm{H}_{3} \mathrm{O}^{+}$), equally to the operation of the instrument in PTR-MS configuration (Blake et al., 2009).

In order to analyse the time response of the instrument, the setup was modified to generate fast switches between $\mathrm{NH}_{3}$-free and $\mathrm{NH}_{3}$ containing air. For this purpose, a small amount of a gaseous $\mathrm{NH}_{3}$ standard $(50 \mathrm{ppm}$, purity grade 5.0), regulated by a mass flow controller could be injected into the respective zero air stream. A 3-way solenoid PTFE (polytetrafluorethylen) valve (1/8", Teqcom, Santa Ana, CA, USA) was used to sub-sample either from the zero air or from the $\mathrm{NH}_{3}$ containing air stream (approxi- mately $150 \mathrm{ppb}$ ). Concentration steps were easily achieved by switching the valve. To avoid memory effects on surfaces of the setup, the tubes - 1/4" and 1/8" OD, PFA (perfluoroalkoxy) - and the valve were heated to about $150^{\circ} \mathrm{C}$ and both, zero and $\mathrm{NH}_{3}$ air lines were continuously flushed. For the same reason, the tubes between valve and HT-CIMS were kept as short as possible. During all these experiments, the system was run for several hours before conducting the test to provide enough equilibration time to create a stable $\mathrm{NH}_{3}$ concentration and zero air, respectively.

The laboratory experiments did not reveal a dependence of the instrument's sensitivity on the concentration of water vapour. However, a non-linear relationship between water vapour concentration and instrumental $\mathrm{NH}_{3}$ background signal was found. It was examined over a humidity range of 0 to $30 \mathrm{mmol} \mathrm{mol}^{-1}$ covering most typical ambient $\mathrm{H}_{2} \mathrm{O}$ concentrations and could be described as:

$c \mathrm{NH}_{3 \text { bckgr }}=-0.681 \cdot\left(c \mathrm{H}_{2} \mathrm{O}\right)^{2}+38.725 \cdot c \mathrm{H}_{2} \mathrm{O}, R^{2}=0.99$,

with $c \mathrm{NH}_{3}$ in units of ppt and $c \mathrm{H}_{2} \mathrm{O}$ in $\mathrm{mmol} \mathrm{mol}^{-1}$.

The magnitude of the variation in instrumental background was in reasonable accordance with results reported by Norman et al. (2007). In contrast to their findings, no significant humidity related change in the detection limit was encountered. The $2 \sigma$ limit of detection corresponded to $460 \mathrm{ppt} \mathrm{NH}$ for a one-second time resolution (within the considered humidity range). When integrating the HT-CIMS signal over $1 \mathrm{~min}$, the detection limit decreased to $90 \mathrm{ppt}$.

At the field site, the HT-CIMS was calibrated using a permeation oven manufactured by LN Industries (Geneva, Switzerland) equipped with a $\mathrm{NH}_{3}$ permeation tube (VICI, Metronics Inc., Poulsbo, WA, USA). In this system the permeation tube is constantly kept at $40^{\circ} \mathrm{C}$ and continuously flushed with dry zero air (obtained from a cylinder of compressed air) at a flow rate of $0.05 \mathrm{STPL} \mathrm{min}{ }^{-1}$. By dilution with the same zero air, a defined $\mathrm{NH}_{3}$ concentration is achieved. In case of the zero air calibration, a citric acid coated dry denuder was added in front of the outlet of the device to strip away potential rests of $\mathrm{NH}_{3}$ to ensure the quality of this calibration. The permeation system was calibrated by directing the gas mixture through an impinger containing acidic solution $\left(\mathrm{H}_{2} \mathrm{SO}_{4}, 0.01 \mathrm{ML}^{-1}\right)$ and subsequent analysis by ion chromatography.

Calibrations were performed at the field site shortly before the slurry applications by guiding the calibration gas with an effective mixing ratio of $68 \mathrm{ppbNH}_{3}$ directly to the PEEK inlet of the HT-CIMS. One additional zero air measurement was conducted after the second fertilisation event. Prior to recording the signal of $\mathrm{NH}_{3}$ concentration, an equilibration time of at least half an hour was allowed to exclude any potential errors due to adsorption effects of the tube manifolds. The calibrations showed a stable sensitivity of the HT-CIMS of $5.73 \mathrm{ncps}$ (cps normalised to $10^{6} \mathrm{cps}$ of $\mathrm{O}_{2}^{+}$) per ppb of $\mathrm{NH}_{3}$ with an instrumental zero air offset of about 300 ppt $\mathrm{NH}_{3}$ in dry conditions. 
Table 2. Slurry properties; $A_{\text {fert }}=$ fertilised area, $V_{\text {slurry }}=$ volume of applied slurry, $\mathrm{DM}=$ dry matter content, $\mathrm{TAN}=$ total ammoniacal nitrogen.

\begin{tabular}{lccccc}
\hline & $\begin{array}{c}A_{\text {fert }} \\
{[\text { ha] }]}\end{array}$ & $\begin{array}{c}V_{\text {slurry }} \\
{\left[\mathrm{m}^{3}\right]}\end{array}$ & $\mathrm{pH}$ & $\begin{array}{c}\mathrm{DM} \\
{[\%]}\end{array}$ & $\begin{array}{c}\text { TAN } \\
{\left[\mathrm{g} \mathrm{L}^{-1}\right]}\end{array}$ \\
\hline 4 August 2009 & 1.23 & 41.0 & $7.82 \pm 0.10$ & $0.99 \pm 0.09$ & $0.87 \pm 0.01$ \\
6 August 2009 & 0.77 & 22.5 & $7.49 \pm 0.19$ & $2.03 \pm 0.35$ & $1.18 \pm 0.05$ \\
\hline
\end{tabular}

\subsection{Flux measurements in the field}

\subsubsection{Experimental site and design}

The capability of HT-CIMS for EC measurements of high $\mathrm{NH}_{3}$ emission fluxes was tested on the occasion of two cattle slurry applications at Oensingen, Switzerland in August 2009 (for a detailed site description see Spirig et al., 2010). The first fertilisation was on an arable field (4 August 2009) and the second on an adjacent grassland field (6 August 2009). The arable site (wheat) had been harvested days earlier with stubbles of $\sim 20 \mathrm{~cm}$ height remaining in low density, and the grassland had been previously cut as well leaving a vegetation cover of only $5 \mathrm{~cm}$ height. The slurry was spread using a tank trailer with splash plate. Table 2 summarises key properties of the applied slurry.

The sonic anemometer was placed onto the freshly fertilised surface at a height of $1.25 \mathrm{ma}$ a.l. (above ground level), whereas the upwind fetch was about 100 and $75 \mathrm{~m}$ in the case of the crop and the grassland field, respectively. The HT-CIMS was installed in an air conditioned container 15-20 $\mathrm{m}$ away from the sonic anemometer at the field border. The sample inlet was placed $25 \mathrm{~cm}$ below the centre of the sonic sensors at $1 \mathrm{~m}$ a.g.1..

\subsubsection{Inlet line}

Since the flux measurement system was situated on the fertilised field and the HT-CIMS was housed in the container adjacent to the site, an inlet tube of $23 \mathrm{~m}$ length was necessary. In order to facilitate fast $\mathrm{NH}_{3}$ measurements despite the long inlet tube, a custom-made tube heating was constructed. The 1/2" (OD) PFA Teflon tube was insulated with silicone foam hose ( $22 \mathrm{~mm}$ ID, $8 \mathrm{~mm}$ wall thickness; Castan, Freiberg, Germany). The heating consisted of four heating wires (Type $\mathrm{KTeS}$, Wisag, Zürich, Switzerland) with a heat production of $22.5 \mathrm{Wm}^{-1}$ each, evenly distributed parallel along the tube. The tube was completely wrapped with heat resistant aluminium-covered glasfiber tape $\left(\right.$ Scotch $^{\circledR}, 3 \mathrm{~m}$, St. Paul, MN, USA). The inlet temperature profile was monitored by K-type thermocouples, fixed at the tube's outer surface inside the wrapping at 5 different locations $(0.05,6.5,12,18$ and $23 \mathrm{~m}$ away from the sample inlet), carefully arranged not to be in direct contact with the heaters. Temperature was regulated and kept at $150{ }^{\circ} \mathrm{C}$ by a proportional-integral-derivative

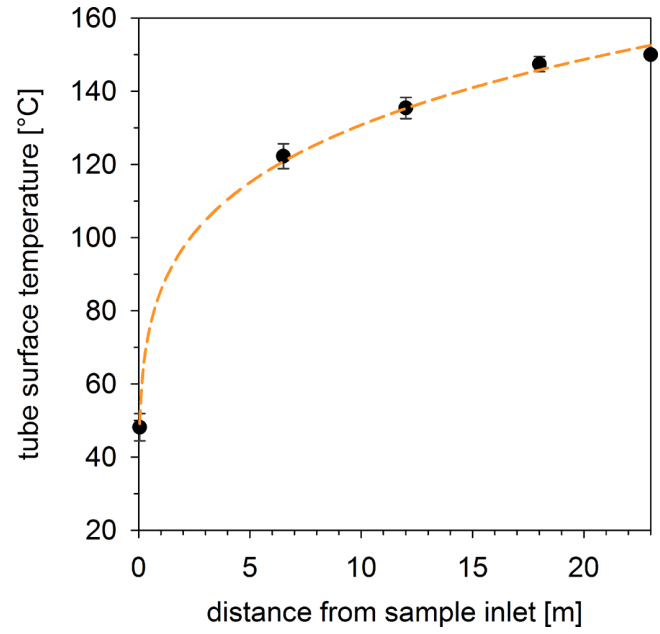

Fig. 2. Average profile of surface temperatures of the 1/2" inlet tube on both days of fertilisation; mean values \pm standard deviation.

(PID) temperature controller using the thermocouple close to the HT-CIMS creating an increasing temperature gradient over the entire inlet line as shown in Fig. 2.

The sample tube was flushed with $\sim 100 \mathrm{STP} \mathrm{L} \mathrm{min}^{-1}$ by a rotary pump (VTE8, Thomas, Memmingen, Germany) installed downstream of the HT-CIMS inlet. The Reynolds number $(R e)$ inside the tube was $R e \approx 4.4 \times 10^{4}$. The cooling effect of the $100 \mathrm{STPL} \mathrm{min}^{-1}$ sample flow outweighed the heating at the first metres of the inlet line. Nevertheless, temperatures above $100{ }^{\circ} \mathrm{C}$ were achieved at about $2.5 \mathrm{~m}$ from the inlet (Fig. 2). Near the end of the $23 \mathrm{~m}$ sample line, a subsample (1.1 STP L min ${ }^{-1}$ ) of the air stream was aspirated towards the HT-CIMS through a $17 \mathrm{~cm}$ long $1 / 8^{\prime \prime}$ (OD) PFA tube heated separately to $150^{\circ} \mathrm{C}$. A side effect of heating the entire sampling tube and the HT-CIMS is the potential to dissociate some of the aerosol particulate matter which could release $\mathrm{NH}_{3}$. This aspect will be discussed in Sect. 4.4. The impact of $\mathrm{NH}_{3}$ attenuation due to wall effects in the entire measurement system, including the heated $23 \mathrm{~m}$ inlet line, was assessed empirically using spectral analysis derived from the EC measurements (see Sect. 2.2.3. Sect. 3.2.2 and Sect. 4.2).

\subsubsection{Eddy covariance flux calculation}

Following the EC method (Baldocchi et al., 1988; Dabberdt et al., 1993), the vertical flux of a trace gas at the sampling point is calculated as the covariance of the discrete time series (average product of the instantaneous deviations from the mean values) of the vertical wind $w(t)$ and concentration $c(t)$ over an averaging period $T_{\mathrm{a}}$ of typically 10 to $30 \mathrm{~min}$. The two time series have to be adjusted to each other by the time lag $\left(\tau_{\mathrm{del}}\right)$ in order to account for the delayed detection of the trace gas, mainly due to the tube transit time: 


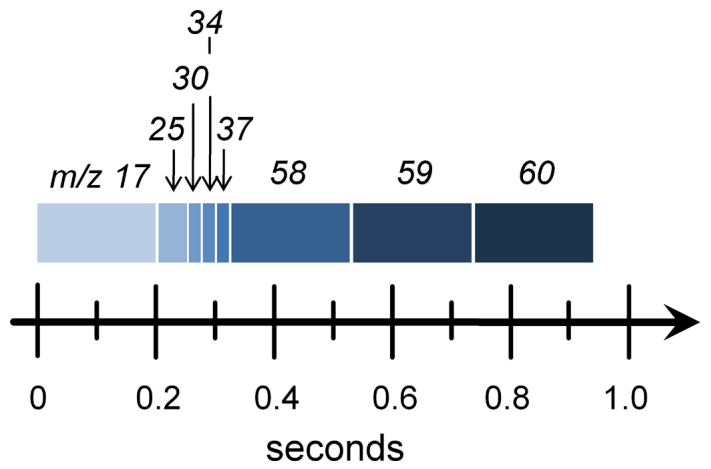

Fig. 3. HT-CIMS measurement cycle with several molecular masses and associated dwell times of $0.2,0.05$ and $0.02 \mathrm{~s}$, respectively.

$$
\begin{aligned}
F_{\text {ECraw }} & =\operatorname{cov}_{\mathrm{wc}}\left(\tau_{\mathrm{del}}\right) \\
& =\left(\frac{\Delta t}{T_{\mathrm{a}}}\right) \cdot \sum_{t=0}^{T_{\mathrm{a}}}(w(t)-\bar{w}) \cdot\left(c\left(t-\tau_{\mathrm{del}}\right)-\bar{c}\right),
\end{aligned}
$$

where $\Delta t=$ time difference between two recordings.

The EC flux is denoted as "raw" here because it needs some additional corrections due to non-ideal measurement conditions (see below). For the concentration time series $c(t)$ the specific characteristics of the HT-CIMS data acquisition have to be considered: within one measurement cycle, the HT-CIMS sequentially scans for selected ion masses with differing dwell times (Fig. 3). In the present field experiment one full measurement cycle of the HT-CIMS was completed within $0.93 \mathrm{~s}$.

In order to derive the EC fluxes, the approach presented by Spirig et al. (2005) was applied. The measurement of an individual ion mass is regarded to be representative for one whole measurement cycle and the respective HT-CIMS data point is replicated at $20 \mathrm{~Hz}$ time resolution until the following cycle is finished, producing a data record with identical time resolution as that of the sonic anemometer (HS Research Anemometer, Gill Instruments Ltd, Lymington, UK). Such gap-filling introduces additional low-pass filtering of the fluxes that can be corrected for as long as the measurements cycle is relatively short (Hörtnagl et al., 2010). As closed path sampling of sticky compounds produces a considerable amount of high-frequency attenuation (Ammann et al., 2006; Ibrom et al., 2007), the low-pass filter effect due to the gap-filling does not significantly influence the flux calculation since it is included in the applied high-frequency correction (Spirig et al., 2005) (see below).

The sonic anemometer data were recorded by a Labview (National Instruments, Austin, Texas, USA) program whilst HT-CIMS data were registered on the same computer by a modified version of Ionicon's software "PTR-MS control 2.5". The latter externally buffered the data in real-time, so that the sonic anemometer program could record both data streams with a common rate of $20 \mathrm{~Hz}$.

In case a turbulent flux is present, the cross covariance function given by Eq. (3) unambiguously peaks at the characteristic time lag of the system (McMillen, 1988). In theory, the time lag corresponds to the residence time of the air in the sampling tube that is determined by the flow rate and the tube volume. For HT-CIMS measurements, the gas residence time in the instrument itself, the length of the measurement cycle and the signal integration time (Fig. 3) add to the expected delay (Spirig et al., 2005). In practice, deviations from the expected time lag can occur due to various reasons such as variations of the pump speed or the wind direction, non-negligible data acquisition and processing time (Leuning and Judd, 1996), or humidity dependent sorption effects on the tube walls (Ibrom et al., 2007). Consequently, we chose to derive $\tau_{\text {del }}$ with a peak detection routine in the covariance function within a given range of plausible lag times. The precision of $F_{\text {ECraw }}$ was calculated according to Wienhold et al. (1994) as the standard deviation $\sigma_{\mathrm{cov}}$ of the covariance function within windows shifted -120 to $-70 \mathrm{~s}$ and +70 to $+120 \mathrm{~s}$ from the expected lag. A reliable identification of the covariance peak and thus of the lag time is possible only if the corresponding flux clearly exceeds $2 \sigma_{\text {cov }}$. For situations when a peak identification was not possible, a fixed lag $\tau_{\text {fix }}$ was derived as the mean of $\tau_{\text {del }}$ obtained from detectable peaks and was used for the calculation of the respective flux $F_{\text {ECraw }}\left(\tau_{\text {fix }}\right) \pm 2 \sigma_{\text {cov }}$. The dilution effect of water vapour on the $\mathrm{NH}_{3}$ flux was accounted for by routinely applying the socalled WPL correction (Webb et al., 1980). This altered the slurry emission fluxes by two per mille at maximum (and by about 0.5 to $1 \mathrm{ng} \mathrm{m}^{-2} \mathrm{~s}^{-1}$, hence a few percent during small fluxes on 15 August 2009, see Sect. 3.2.3).

Ogives $\left(O g_{\mathrm{wc}}\right)$ (e.g. Desjardins et al., 1989; Oncley et al., 1989) provide information about the contribution of different turbulent frequencies to the flux. They are cumulated co-spectra integrating over all frequencies of the finite cospectrum $\left(\mathrm{Co}_{\mathrm{wc}}\right)$ of the covariance function:

$$
\begin{aligned}
O g_{\mathrm{wc}}\left(f_{\mathrm{m}}\right) & =\sum_{i=1}^{m} \operatorname{Co}_{\mathrm{wc}}\left(f_{i}\right), \\
f_{i} & =\frac{i}{T_{\mathrm{a}}} ; m=1,2, \ldots,\left[\frac{T_{\mathrm{a}}}{2 \times \Delta t}\right] .
\end{aligned}
$$

The value of the function at a certain frequency $\left(f_{\mathrm{m}}\right)$ represents the integrated co-spectral contribution to $F_{\text {ECraw }}$. Ammann et al. (2006) presented an ogive-based empirical correction that accounts for signal loss due to insufficient time resolution of the analytical system. For EC flux determination of non- passive tracers, like $\mathrm{NH}_{3}$ and $\mathrm{H}_{2} \mathrm{O}$, the major constraint leading to such attenuation is the ad- and desorption of molecules on surfaces inside the analytical system, limiting the time response. In our measurement setup, this occurred to some degree in the $23 \mathrm{~m}$ inlet line as well as inside the HT-CIMS. Implying co-spectral similarity, the 
attenuation factor is derived by comparison with the ogive of the sensible heat flux that is assumed to be undamped.

As a consequence of the humidity interference on the $\mathrm{NH}_{3}$ measurement of the HT-CIMS (Eq. 2), variations in ambient water vapour concentration due to turbulent $\mathrm{H}_{2} \mathrm{O}$ flux provoke fluctuations in the $\mathrm{NH}_{3}$ signal appearing as an artificial contribution to the $\mathrm{EC} \mathrm{NH}_{3}$ flux. Therefore, concentrations and EC fluxes of water vapour were monitored in parallel by a conventional open path infrared gas analyser (IRGA; Li-7500, LI-COR Biosciences, Lincoln, USA) operated together with a second ultrasonic anemometer (Ammann et al., 2007). The HT-CIMS $m / z, 37$ signal was calibrated against the water vapour concentration of the IRGA to calculate EC $\mathrm{H}_{2} \mathrm{O}$ fluxes by HT-CIMS as outlined above.

The water correction (Eq. 2) was performed on the high resolution $\mathrm{NH}_{3}$ time series before it was processed to derive EC fluxes, employing the $\mathrm{H}_{2} \mathrm{O}$ concentrations also recorded by the HT-CIMS. The amount of flux interference was then quantified as the difference between the $\mathrm{EC} \mathrm{NH}_{3}$ fluxes calculated with and without this correction. A potential error source could be the fact that strictly speaking the HTCIMS measures $\mathrm{NH}_{3}$ and $\mathrm{H}_{2} \mathrm{O}$ not simultaneously (Fig. 3). However, the corresponding time delay of $0.2 \mathrm{~s}$ is definitely smaller than the response time limitation due to the highfrequency damping in the EC measurement of both, $\mathrm{H}_{2} \mathrm{O}$ and $\mathrm{NH}_{3}$ fluxes. Therefore, we neglected the influence of non-synchronous mass scans on the water vapour correction.

\section{Results}

\subsection{Improvement of time response with the new drift tube}

The reduced residence time and altered materials in the new prototype drift tube had no significant enhancing effect on the instrumental time response. In contrast, heating of the drift tube from $100^{\circ} \mathrm{C}$ to $180^{\circ} \mathrm{C}$ significantly improved the time response to step changes of the $\mathrm{NH}_{3}$ concentration as observed in laboratory experiments (Fig. 4). Following the mathematical description given by Whitehead et al. (2008) and Ellis et al. (2010), the decay was characterised by a biexponential function:

$$
c \mathrm{NH}_{3}(t)=A_{1} \cdot \exp \left(-\frac{\left(t-t_{0}\right)}{\tau_{1}}\right)+A_{2} \cdot \exp \left(-\frac{\left(t-t_{0}\right)}{\tau_{2}}\right),
$$

with $t_{0}=$ time of concentration step, time constants $\tau_{1}$ and $\tau_{2}$ and coefficients $A_{1}$ and $A_{2}$, where $A_{1}+A_{2}=c \mathrm{NH}_{3}\left(t_{0}\right)$.

The two exponential terms describe the superposition of a fast and a slow reaction of the system to a concentration change (Ellis et al., 2010). The experiment revealed response times $\tau_{1}=1.96 \mathrm{~s}$ and $\tau_{2}=38.23 \mathrm{~s}$ with the PEEK drift tube at $100^{\circ} \mathrm{C}$. According to the relative magnitude of the coefficients $A_{1}$ and $A_{2}$, the faster exponential function was responsible for $68 \%$ of the decrease. With the drift tube heated to

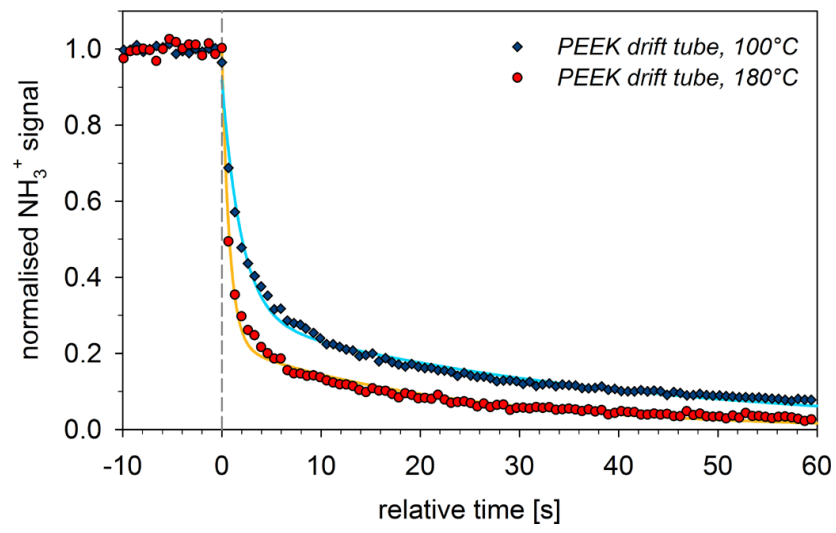

Fig. 4. Improvement of HT-CIMS time response by heating of the new prototype PEEK drift tube: switch from $\sim 150 \mathrm{ppb}$ to $0 \mathrm{ppb} \mathrm{N_{3 }}$; symbols show measurement data and solid lines represent the respective fits according to Eq. 5 .

$180{ }^{\circ} \mathrm{C}, \tau_{1}$ and $\tau_{2}$ were reduced to $0.77 \mathrm{~s}$ and $23.06 \mathrm{~s}$, respectively. In this case, the fast exponential decay accounted for $77 \%$ of the overall step change.

\subsection{Field measurements}

\subsubsection{Detection of turbulent fluctuations and covariances}

In order to illustrate the fast response measurements in the field and the detection of turbulent fluctuations, Fig. 5 shows some exemplary high-resolution time series of the raw data of vertical wind speed $(w)$, air temperature $(T), \mathrm{NH}_{3}$ and $\mathrm{H}_{2} \mathrm{O}$ concentration. The data on the left panels were recorded at noon, shortly after the spreading of slurry on the cropland. The temperature time series revealed typical flux signatures, evident as tooth-saw shaped structures that are known to be characteristic for convective elements participating in the vertical transport (Kaimal and Businger, 1971), as well as up- and downdrafts emerging as cyclic features. Similar patterns were also present in the course of the $\mathrm{H}_{2} \mathrm{O}$ and $\mathrm{NH}_{3}$ time series. Changes occurred primarily on timescales ranging from one second to a few tenths of seconds. The $\mathrm{NH}_{3}$ time series is characterised by high temporal dynamics with a range of minimum to maximum values of about $80 \mathrm{ppb}$ to $3100 \mathrm{ppb}$. Qualitatively this suggests that the field setup was fast enough to capture the turbulent $\mathrm{NH}_{3}$ fluctuations.

The data in the right-hand panels in Fig. 5 were recorded above the grassland, 9 days after the fertilisation of that site when the $\mathrm{NH}_{3}$ fluxes were expected to be much smaller and in a potentially bi-directional exchange regime again (Flechard et al., 2010). As a contrasting instance, they illustrate a situation when positive correlations of temperature and $\mathrm{H}_{2} \mathrm{O}$ were observed, but no (positive or negative) relation for $\mathrm{NH}_{3}$ was apparent. In this case there was either no prevailing flux of $\mathrm{NH}_{3}$ or it was not detectable by the system. 

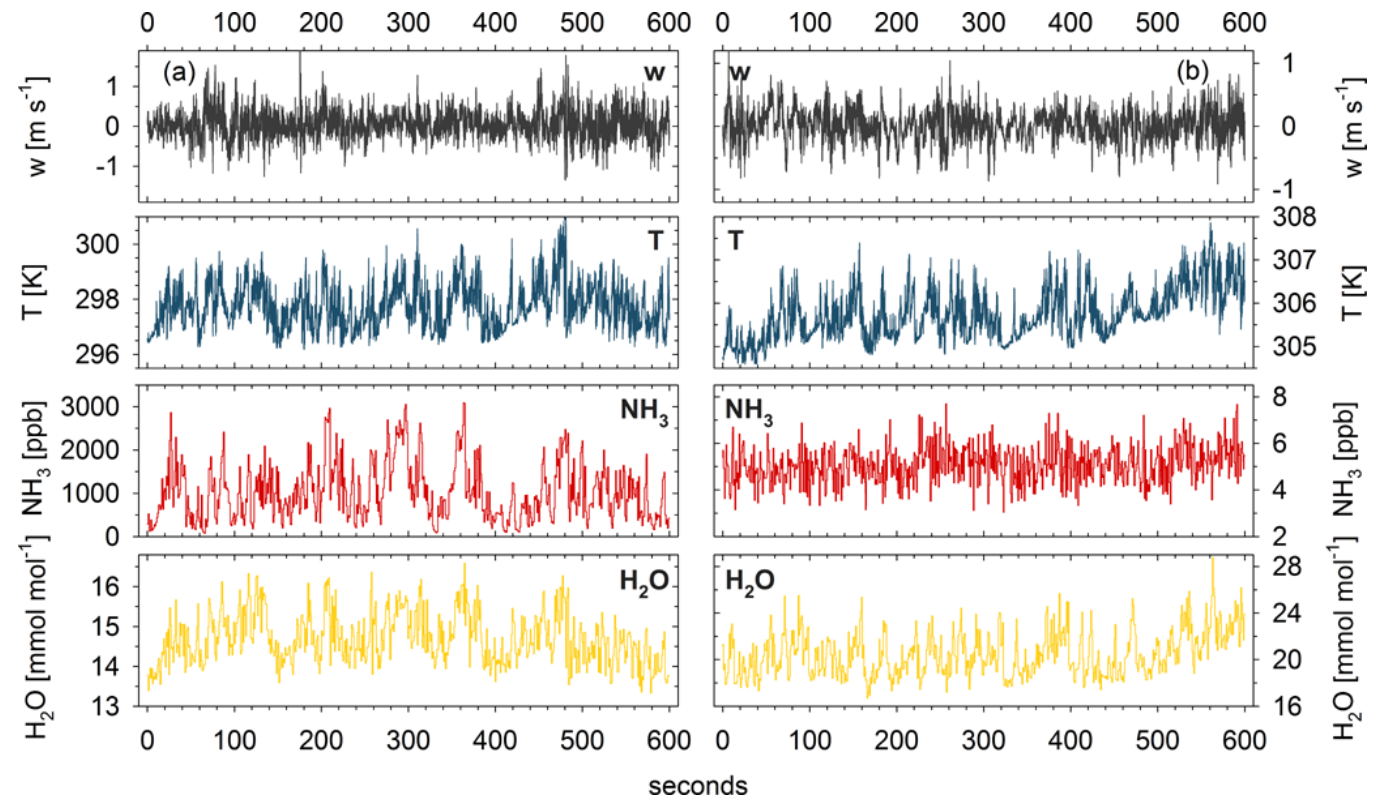

Fig. 5. Exemplary $20 \mathrm{~Hz}$ time series of $w, T, \mathrm{NH}_{3}$ and $\mathrm{H}_{2} \mathrm{O}$ obtained from sonic anemometer and $\mathrm{HT}-\mathrm{CIMS}$ measurements on (a) 4 August 2009, 13:20-13:30 and (b) 15 August 2009, 13:30-13:40.

The covariance functions in Fig. 6 support the qualitative picture of the time series given above. It was possible to identify distinct maxima in all covariance functions for $4 \mathrm{Au}-$ gust 2009 (upper panels). The peak value in the function corresponds to the raw vertical flux of the respective scalar quantity. For $\mathrm{NH}_{3}$, the associated lag time was $-2.85 \mathrm{~s}$. Mean empirically derived lag times during both fertilisation events were $-2.98 \pm 0.14 \mathrm{~s}$ in case of $\mathrm{NH}_{3}$ and $-2.44 \pm 0.12 \mathrm{~s}$ for $\mathrm{H}_{2} \mathrm{O}$, respectively. On average, the $\mathrm{NH}_{3}$ lag deviated from that of the water vapour flux by $-0.54 \mathrm{~s}$. However, since $\mathrm{H}_{2} \mathrm{O}\left(\mathrm{m} / \mathrm{z}\right.$ 37) was scanned $0.2 \mathrm{~s}$ after $\mathrm{NH}_{3}(\mathrm{~m} / \mathrm{z}, 17)$ in the HT-CIMS measurement cycle (see Fig. 3), the actual lag difference amounted to $-0.74 \mathrm{~s}$. These lag times thus exceeded the calculated theoretical residence times in the measurement system of about $1.75 \mathrm{~s}$ for $\mathrm{NH}_{3}$ and $1.64 \mathrm{~s}$ for $\mathrm{H}_{2} \mathrm{O}$, which account for the duration of gas transport in the inlet line and the instrument itself and for the delay due to the sequential mass scanning (Fig. 3). Comparing the covariance functions of $\mathrm{NH}_{3}$ and $\mathrm{H}_{2} \mathrm{O}$ to that of temperature reveals similar shapes with slightly broader peaks. Overall, the observed covariance functions indicate the suitability of the system for EC flux measurements.

The second set of covariance functions shown in the lower segment of Fig. 6 demonstrates the limitations of the $\mathrm{NH}_{3}$ flux identification. Still, distinct fluxes of sensible heat and water vapour appear as peak covariances, but in case of $\mathrm{NH}_{3}$ it was not possible to unambiguously determine a peak value in the covariance function corresponding to the $\mathrm{NH}_{3}$ flux.

The precision and detection limit of a flux measurement do not necessarily correspond to each other and should be treated separately. The noise in the baseline of the covariance function used as a measure for the precision (Sect. 2.2.3) was about proportional to the magnitude of the flux and therefore the large fertiliser emissions had a larger absolute uncertainty than smaller fluxes. In order to obtain a flux detection limit (against a zero flux), the standard deviation of the covariance function was averaged during a phase (15 August 2009) when no significant covariance function peaks could be detected. The analysis yielded a $2 \sigma$-flux detection limit of $4.5 \pm 1.5 \mathrm{ng} \mathrm{m}^{-2} \mathrm{~s}^{-1}$ for half hourly averaging intervals.

\subsubsection{High-frequency attenuation}

Figure 7 shows median ogives of $\mathrm{NH}_{3}, \mathrm{H}_{2} \mathrm{O}$ and sensible heat fluxes during the period after the spreading of the slurry on the grassland field. The ogive values are normalised to the respective $F_{\mathrm{ECraw}}$ so that they range from 0 to $100 \%$ of the flux. The relatively uniform wind speed and unstable stratification on that day allowed a direct statistical evaluation of the individual ogives without conversion to dimensionless frequency. Contrasting the ogive of the $\mathrm{NH}_{3}$ flux with that of the undamped sensible heat flux revealed a clear attenuation of the $\mathrm{NH}_{3}$ flux at higher frequencies. The dashed lines in Fig. 7 display the ogives of the $\mathrm{NH}_{3}$ and $\mathrm{H}_{2} \mathrm{O}$ fluxes after adjusting to the reference sensible heat flux ogive at a threshold frequency of $0.065 \mathrm{~Hz}$. At frequencies above $0.065 \mathrm{~Hz}$ the $\mathrm{NH}_{3}$ ogive slowly begins to deviate from the reference. However, substantial differences of more than $5 \%$ occur at frequencies larger than $0.18 \mathrm{~Hz}$. The ogive of the $\mathrm{H}_{2} \mathrm{O}$ flux follows the sensible heat flux ogive somewhat longer, experiencing deviation larger than $5 \%$ only around $0.47 \mathrm{~Hz}$. The $\mathrm{NH}_{3}$ flux was attenuated by about $30 \%$ compared to the flux 

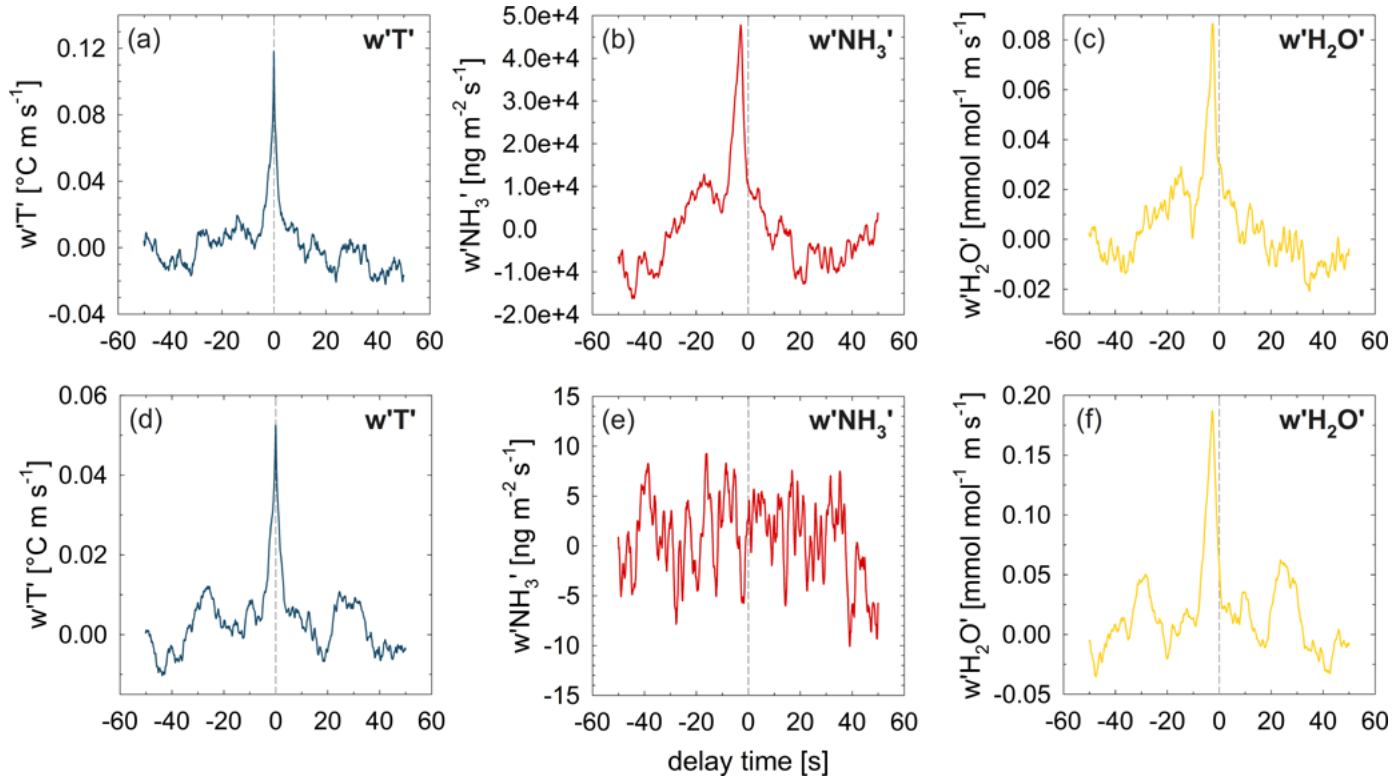

Fig. 6. Two examples of a set of covariances as a function of time shift between the scalar time series and vertical wind time series: (a-c) 4 August 2009, 13:20-13:30 and (d-f) 15 August 2009, 13:30-13:40.

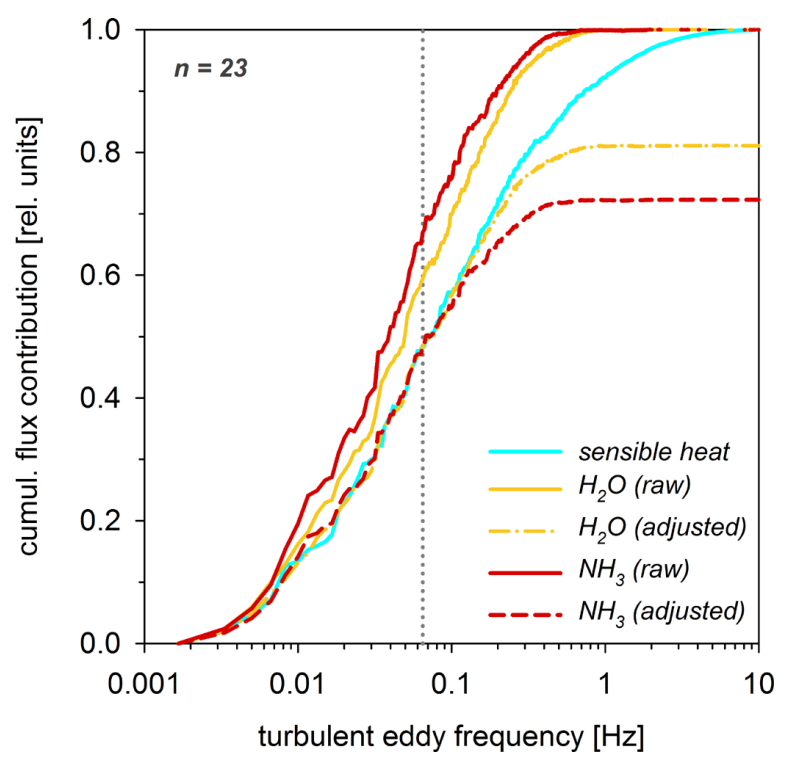

Fig. 7. Normalised median ogives of sensible heat, $\mathrm{H}_{2} \mathrm{O}$ and $\mathrm{NH}_{3}$ flux on 6 August 2009, 11:10-15:00; $U=1.47 \pm 0.5 \mathrm{~ms}^{-1}$, $(z-d) L^{-1}=-0.47 \pm 0.3$; illustrating the effect of high-frequency damping on $\mathrm{NH}_{3}$ and $\mathrm{H}_{2} \mathrm{O}$ flux: dashed lines represent the ogives of the dampened fluxes adjusted to the ogive of the sensible heat fluxes at a threshold frequency of $0.065 \mathrm{~Hz}$ (dotted line).

of sensible heat, the $\mathrm{H}_{2} \mathrm{O}$ flux only by about $20 \%$. Between the threshold and the low frequency end, the curves agreed considerably well.

As demonstrated in Fig. 8, the damping of the flux was parameterised as a function of horizontal wind speed in order

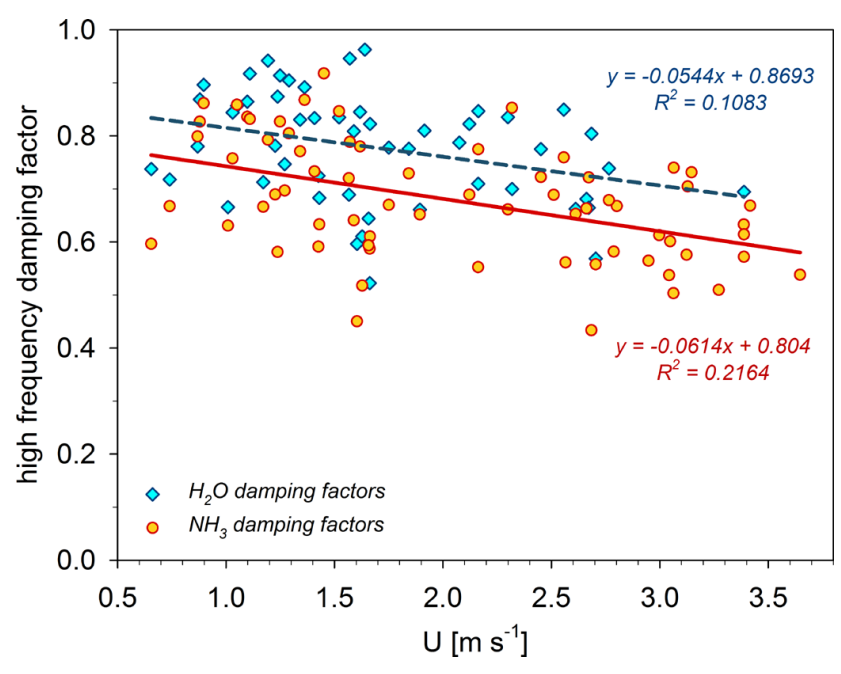

Fig. 8. $\mathrm{NH}_{3}$ and $\mathrm{H}_{2} \mathrm{O}$ damping factors vs. horizontal wind speed $(U)$ on 4 August 2009 and 6 August 2009.

to decrease the scatter of the single values (Ammann et al., 2006). Damping factors of the $\mathrm{NH}_{3}$ flux showed more attenuation than those for the $\mathrm{H}_{2} \mathrm{O}$ flux with decreasing values for both quantities at higher wind speeds.

\subsubsection{Concentrations and fluxes following slurry application}

Figure 9 gives a picture of the predominant meteorological conditions for the two days of fertilisation investigated here. The temperatures (about 15 to $24^{\circ} \mathrm{C}$ and 15 to $27^{\circ} \mathrm{C}$, 


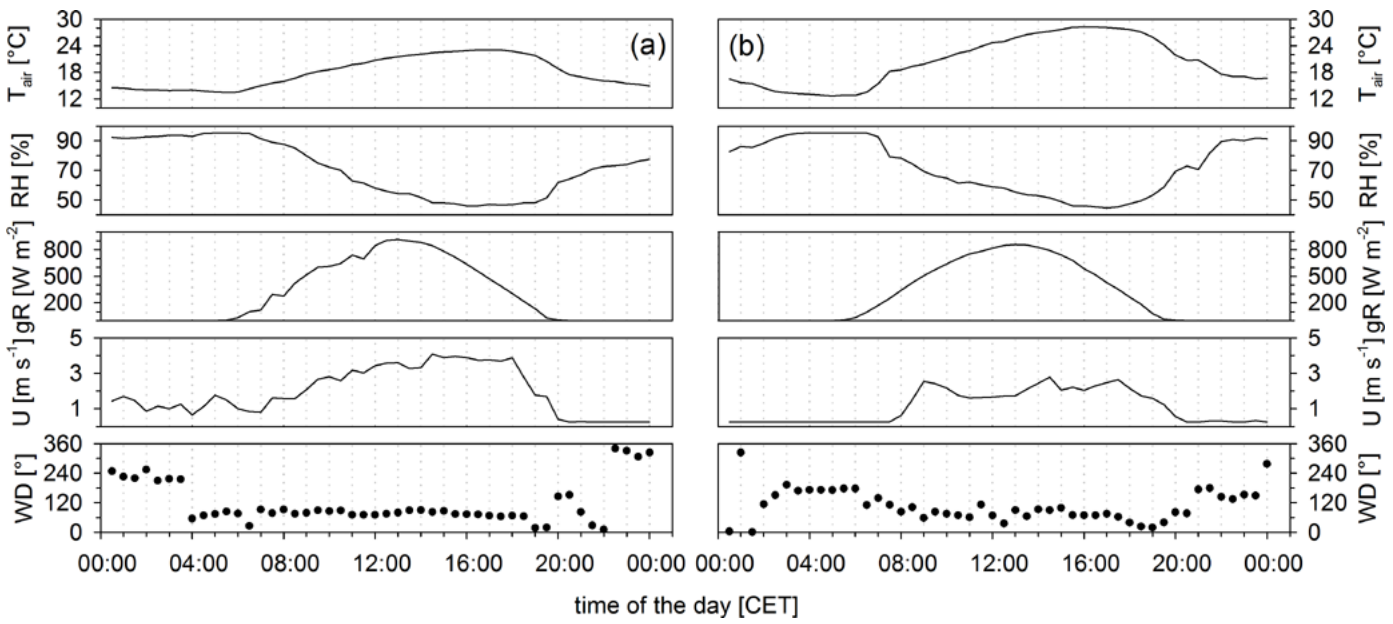

Fig. 9. Air temperature $\left(T_{\text {air }}\right)$, relative humidity $(\mathrm{RH})$, global radiation $(g R)$, horizontal wind speed $(U)$ and wind direction $(W D)$ measured at $3 \mathrm{~m}$ a.g.l. at the Oensingen site on (a) 4 August 2009 and (b) 6 August 2009.

respectively, during daytime) and solar radiation intensities were quite high, whilst relative humidity was below $50 \%$ in the afternoon and highest in the early morning hours. There was no rain; winds prevailed from easterly directions with wind speeds of up to 4 and $2.5 \mathrm{~ms}^{-1}$, respectively.

The series of data highlighted in the following reflect periods of well defined turbulence, selected due to criteria of the integral turbulence characteristics (Foken and Wichura, 1996). Figure 10 demonstrates the course of $\mathrm{NH}_{3}$ concentrations during daytime on both sites. Failures of the combined sonic and HT-CIMS data acquisition system on the first day of operation resulted in some data gaps on $4 \mathrm{Au}-$ gust 2009. During slurry spreading, the 10 min moving average $\mathrm{NH}_{3}$ concentrations recorded by the HT-CIMS quickly rose to around $1.2 \mathrm{ppm}$ on 4 August 2009 and to more than $2.3 \mathrm{ppm}$ on 6 August 2009. The peak was followed by a fast decay of the concentrations down to around $80 \mathrm{ppb}$ and $40 \mathrm{ppb}$ in the evening. The maximum $\mathrm{NH}_{3}$ concentration on 4 August 2009 was most probably higher than measured, since the first minutes of the slurry spreading could not be captured. The data revealed enormous concentration fluctuations. Within the first hour, rapid concentration changes of more than $2 \mathrm{ppm}$ were monitored, even when averaging over $1 \mathrm{~min}$. On 6 August 2009, the one minute averaged concentrations covered a range of more than $5 \mathrm{ppm} \mathrm{NH}_{3}$ within several minutes.

The course of measured $\mathrm{NH}_{3}$ fluxes strongly resembled that of the concentrations (Fig. 10). On 6 August 2009 the maximum recorded emission flux of about $150 \mu \mathrm{g} \mathrm{m}^{-2} \mathrm{~s}^{-1}$ occurred almost immediately after the spreading of the slurry. The emissions declined very fast, so that the majority of the time-integrated emissions happened within the first and second hour after fertilisation. The same holds for 4 August 2009. Unfortunately, the data gap at the very beginning of this experiment also affected the first half hour of the slurry spreading. Here, the highest measured flux was about $107 \mu \mathrm{g} \mathrm{m}^{-2} \mathrm{~s}^{-1}$. In the evening, the emissions decreased to roughly $1 \mu \mathrm{g} \mathrm{m}^{-2} \mathrm{~s}^{-1}$ on both days.

\subsubsection{Water vapour fluxes and their interference}

Water vapour EC fluxes derived from HT-CIMS measurements were compared with corresponding fluxes from the nearby EC system using a common IRGA analyser. Figure 11 shows good agreement between $\mathrm{H}_{2} \mathrm{O}$ fluxes observed by both systems during two exemplary days. This demonstrates that, like in the proton transfer configuration (Ammann et al., 2006), the instrument was capable to capture EC $\mathrm{H}_{2} \mathrm{O}$ fluxes in its electron transfer mode as well.

As outlined in Sect. 2.2.3, variations in water vapour concentration due to turbulent $\mathrm{H}_{2} \mathrm{O}$ flux provoke fluctuations in the raw $\mathrm{NH}_{3}$ signal inside the instrument appearing as EC $\mathrm{NH}_{3}$ flux if not corrected for by Eq. (2). In order to check and illustrate the quantitative effect of the $\mathrm{H}_{2} \mathrm{O}$ interference, we additionally analysed flux measurements in a situation of background surface-atmosphere $\mathrm{NH}_{3}$ exchange, i.e. with low concentrations and fluxes unaffected by slurry related emissions (see Flechard et al., 2010). Figure 12 shows such an exemplary day. The diurnal course of $\mathrm{NH}_{3}$ fluxes shows a depositional pattern in the morning and mainly zero or very small emission fluxes at noon. The interference effect of the $\mathrm{H}_{2} \mathrm{O}$ fluxes did not substantially superimpose on the uncorrected $\mathrm{NH}_{3}$ fluxes $\left(<2.1 \mathrm{ng} \mathrm{m}^{-2} \mathrm{~s}^{-1}\right.$, see Fig. 12, upper panel). The $\mathrm{NH}_{3}$ interference fluxes scaled with the $\mathrm{H}_{2} \mathrm{O}$ fluxes by a ratio of $0.17 \pm 0.08 \mathrm{ng} \mathrm{NH}_{3} / \mathrm{mmol} \mathrm{H}_{2} \mathrm{O}$. During the fertilisation related emissions this translated into a relative flux interference in the sub-\%o range. Even in the example of background exchange conditions on 15 August 2009 (Fig. 12), the $\mathrm{H}_{2} \mathrm{O}$ correction was smaller than the precision of the flux determination. 

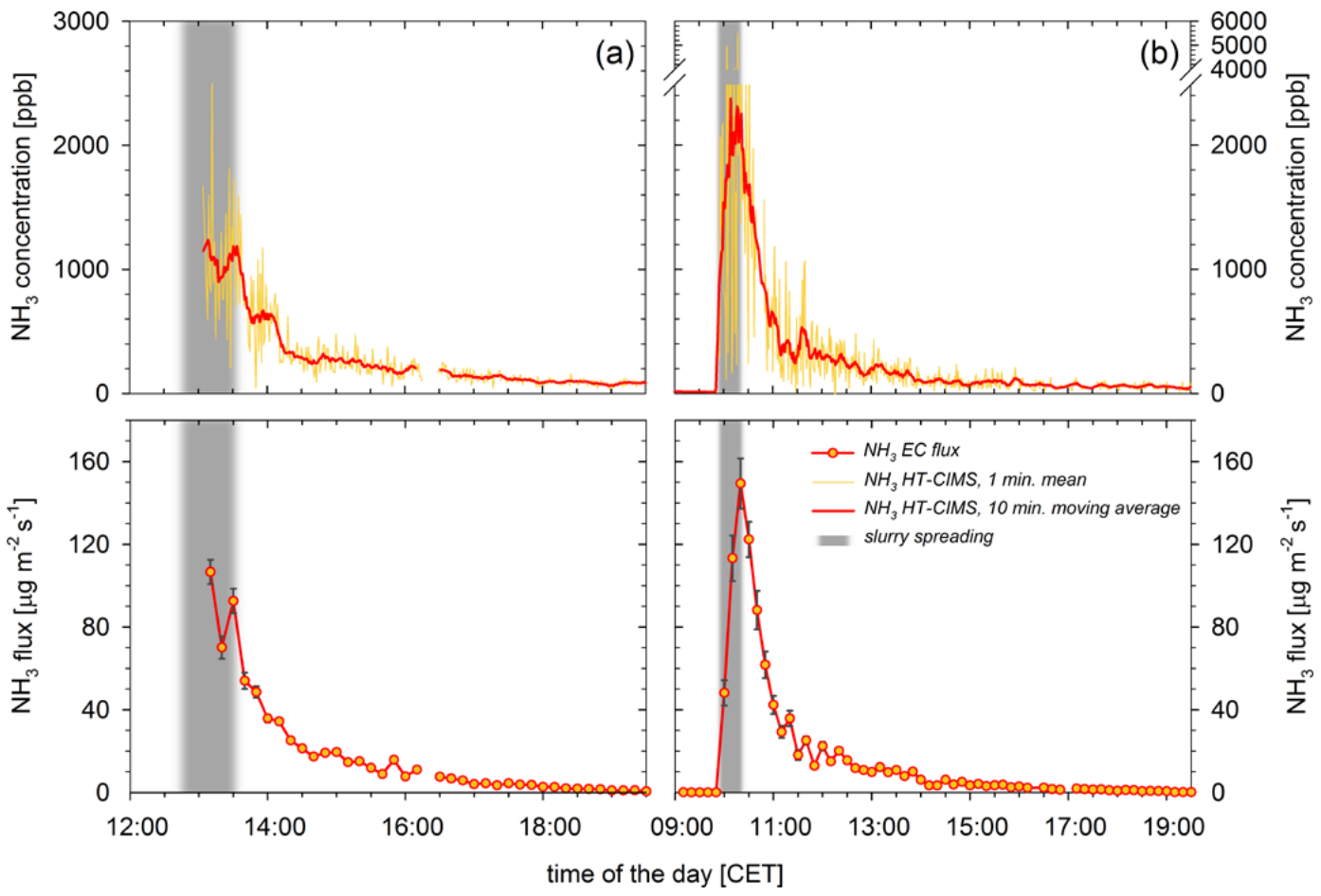

Fig. 10. $\mathrm{NH}_{3}$ concentrations and EC fluxes measured at $1 \mathrm{~m}$ a.g.l. during and after the spreading of slurry on (a) 4 August 2009 (crop stubble field) and (b) 6 August 2009 (cut grassland); vertical error bars of $\mathrm{NH}_{3}$ fluxes represent the precision of the flux, shaded areas indicate the period of slurry spreading affecting the fetch of the measurement.

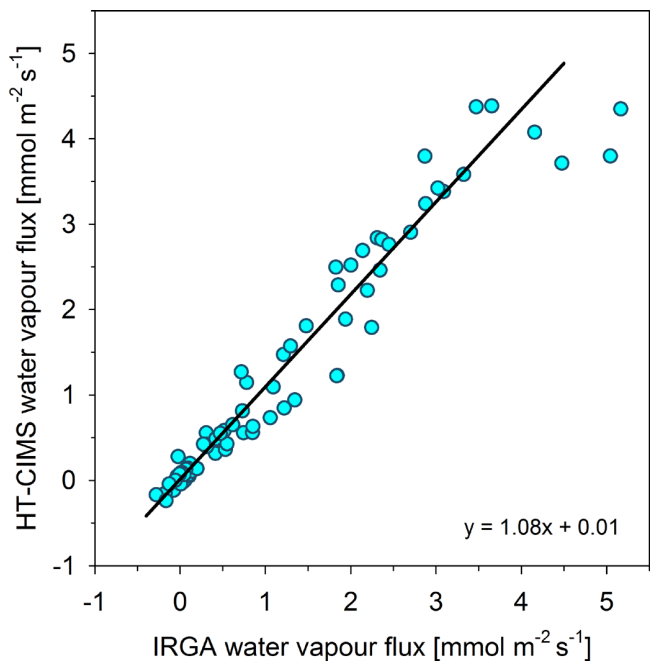

Fig. 11. Fluxes of water vapour measured by IRGA and HT-CIMS; Williamson-York bivariate fit (Cantrell, 2008).

\section{Discussion}

\subsection{Time response}

$\mathrm{NH}_{3}$ is known to be among the stickiest trace gases due to its strong dipole (Appl, 1999) causing a high affinity towards

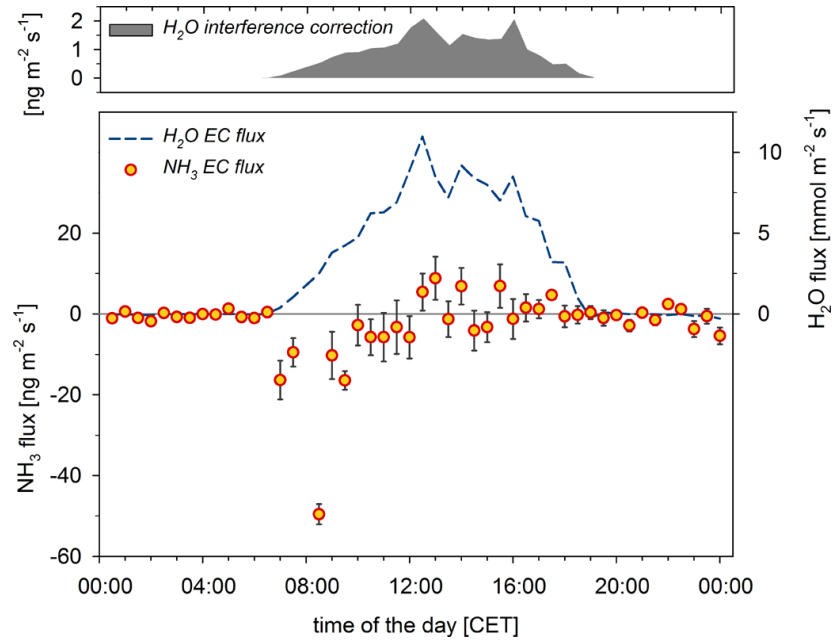

Fig. 12. Lower panel: $\mathrm{EC}$ fluxes of $\mathrm{NH}_{3}$ (evaluated at constant delay time $\tau_{\text {fix }}$, raw $\mathrm{NH}_{3}$ data are corrected for $\mathrm{H}_{2} \mathrm{O}$ interference) and of $\mathrm{H}_{2} \mathrm{O}$ during conditions of small $\mathrm{NH}_{3}$ exchange fluxes 9 days after the grassland fertilisation on 15 August 2009; upper panel: amount of $\mathrm{NH}_{3}$ flux due to $\mathrm{H}_{2} \mathrm{O}$ interference.

surfaces. A conceptual picture of $\mathrm{NH}_{3}$ adsorption emanates from the assumption that the surfaces provide a finite number of sorption sites: the less exchange sites exist and the 
more molecules are present, the faster the sites are saturated, hence the faster performs the instrument or tube. In addition, heating decreases the amount of $\mathrm{H}_{2} \mathrm{O}$ molecules adsorbed at walls and hence lowers the impact on $\mathrm{NH}_{3}$ molecules (Ellis et al., 2010), since both species undergo strong hydrogen bonding with each other.

In order to facilitate a fast time response it seems vital to provide inert materials (i.e. low surface energy, permeability) which can be heated. The HT-CIMS instrument presented in our study is provided with components made exclusively of PEEK (inert, can be heated $>200^{\circ} \mathrm{C}$ ) and Siltek-coated steel. The results from the laboratory tests (Sect. 3.1) indeed revealed that especially heating promotes a fast time constant. The modified HT-CIMS resolved $\mathrm{NH}_{3}$ concentration steps much better than in the configuration by Norman et al. (2007). Recently, Mikoviny et al. (2010) explored the time resolution for $\mathrm{NH}_{3}$ with a modified high temperature PTR-MS (glass drift tube, altered ion source geometry), operated at $200^{\circ} \mathrm{C}$. They found a very fast instrumental response time of $0.3 \mathrm{~s}$, confirming the positive impact of high temperatures.

Although there is not a completely consistent picture in the few studies looking at the performance of various tubing materials with $\mathrm{NH}_{3}$, it becomes evident that PFA is probably the best suited material which still resists high temperatures (Mukthar et al., 2003; Shah et al., 2006). Additionally, Silcosteel performs slightly better than stainless steel (Whitehead et al., 2008). Ellis et al. (2010) demonstrated how $\mathrm{NH}_{3}$ tends to be adsorbed more severely on inner walls of PFA tubes with smaller concentration steps and increasing sample air humidity. They confirmed that heating (to $40^{\circ} \mathrm{C}$ ) improves the time response to $\mathrm{NH}_{3}$ concentration changes.

The inlet line used for the EC field measurements operated close to ambient pressure and had a large surface in contact with the sample gas. It was therefore equally or even more important to reduce damping effects in the tube as much as possible. Considering the findings mentioned above, the gas inlet line was made of inert PFA which can be heated to more than $100^{\circ} \mathrm{C}$. In this way, the adsorption of $\mathrm{NH}_{3}$ on walls and thus the attenuation of $\mathrm{NH}_{3}$ variations in the EC flux system were expected to be reduced. Massmann and Ibrom (2008) presented a mathematical framework to describe the attenuation of $\mathrm{H}_{2} \mathrm{O}$ fluctuations in a closed path EC system. Based on the Hertz-Knudsen-Schrage Equation (e.g. Marek and Straub, 2001), their model described the net surface adsorption/desorption mass flux of $\mathrm{H}_{2} \mathrm{O}$ to and from tube walls being dependent on the square root of gas (and surface) temperature. However, they found that a purely analytical description of the attenuation in tubes for sticky molecules like $\mathrm{H}_{2} \mathrm{O}$ (and consequently $\mathrm{NH}_{3}$ ) was not yet possible. In their review, Davidovits et al. (2006) summarised that the mass accommodation of $\mathrm{H}_{2} \mathrm{O}$ and also of $\mathrm{NH}_{3}$ on $\mathrm{H}_{2} \mathrm{O}$ layers decreases non-linearly (near exponentially) with increasing temperature. There is no empirically verified physical model of $\mathrm{NH}_{3}$ sorption for materials present in instruments and inlet tubes and so far there seems to be a lack of comprehensive mechanistic understanding of such processes. Nevertheless, it is evident that temperature plays a central role in the mechanisms involved with sorption of $\mathrm{NH}_{3}$ and $\mathrm{H}_{2} \mathrm{O}$ on interfaces. We speculate that the existence of liquid and molecular $\mathrm{H}_{2} \mathrm{O}$ layers inside the HT-CIMS and the inlet tube can be suppressed (to a large degree) by heating the surfaces considerably above $100^{\circ} \mathrm{C}$ which in turn significantly reduces the stickiness of $\mathrm{NH}_{3}$ on the involved walls.

Furthermore, the use of a strongly heated inlet line also prevented from condensation of $\mathrm{H}_{2} \mathrm{O}$ that might trap $\mathrm{NH}_{3}$ (Norman et al., 2009), which can re-evaporate from the inner inlet surfaces when these are drying (Hensen et al., 2009; Ellis et al., 2010). The tube temperature (Fig. 2) rose to above $100^{\circ} \mathrm{C}$ shortly after the sample inlet and was much higher than in previous studies addressing $\mathrm{NH}_{3}$ measurements (e.g. Shaw et al., 1998; Famulari et al., 2004; Whitehead et al., 2008; Benson et al., 2010; Ellis et al., 2010; von Bobrutzki et al., 2010). Heating the inlet is constrained not only by the choice of material but also by the requirement that the inlet must not become a source of heat interfering with the ultrasonic anemometer measurement. In the present study, the sensible heat flux did not indicate any alteration by the tube heating fixed in direct proximity to the anemometer.

\subsection{High-frequency attenuation}

Slurry spreading over an agricultural field offers a unique test for the time behaviour of the setup as it provides high emissions and the turbulent nature of the vertical fluxes produces flux contributions over a large frequency range.

In closed path systems the turbulence related concentration fluctuations of different compounds can be retarded with varying time constants dependent on their stickiness. The fact that the maxima in the covariance functions for $\mathrm{NH}_{3}$ and $\mathrm{H}_{2} \mathrm{O}$ were considerably delayed to each other (Sect. 3.2.1) demonstrates that $\mathrm{NH}_{3}$ was subjected to memory effects in the inlet line even more than $\mathrm{H}_{2} \mathrm{O}$. Like in our measurements, it has been observed earlier that water vapour does not behave like a passive tracer, either (Ammann et al., 2006; Ibrom et al., 2007). The applied high-frequency correction as a function of horizontal wind speed showed a $10 \%$ larger damping of the $\mathrm{NH}_{3}$ flux compared to the $\mathrm{H}_{2} \mathrm{O}$ flux. The significant high-frequency losses were promoted by the low measurement height of only $1 \mathrm{~m}$ a.g.l. (with a short vegetation cover) leading to a considerable weight of higherfrequent flux contributions (Kaimal and Finnigan, 1994). This height was chosen to minimise the extension of the footprint given the relatively small field sizes. It has to be noted that this situation is particularly challenging for EC measurements of sticky compounds. Measuring at higher levels will diminish the effect of high-frequency damping considerably and thus improve the performance of the EC system.

Our high-frequency loss correction implies that below a frequency of $0.065 \mathrm{~Hz}$ turbulent variations of $\mathrm{NH}_{3}$ passed the 
inlet line undamped. This is perhaps an oversimplification as the response of $\mathrm{NH}_{3}$ step changes could be described by the superposition two exponential decays (Eq. 5) with the slower decay time constant being in the order of tens of seconds and more. Compared to the ogive of the sensible heat flux, the damping-adjusted ogive of the $\mathrm{NH}_{3}$ flux showed a very good agreement from $0.065 \mathrm{~Hz}$ down to the lowest frequency (Fig. 7), suggesting no attenuation in this range. However, if the slow decay function involved a nearly uniform damping over all frequencies, there is potential risk for a systematic underestimation of the damping that would not become obvious in the ogives, but we did not find any other indication for such an effect.

The observed attenuation is likely to increase with the usage time of the tube as the inner surfaces are getting dirty and the sorption effects might become stronger (Leuning and Judd, 1996; Ibrom et al., 2007). In light of the complexity of the processes involved with sorption related attenuation we applied the empirical high-frequency attenuation correction. As long as easily identifiable $\mathrm{NH}_{3}$ fluxes are present this could, for instance, be done on a day by day approach allowing to detect systematic changes in the response function e.g. by an increasing damping due to tube ageing.

Ellis et al. (2010) showed that the magnitude of $\mathrm{NH}_{3}$ concentration steps influences the sorption related time response in tubes with high concentration steps in heated tubes being resolved best. This suggests that the attenuation of $\mathrm{NH}_{3}$ could be dependent on the magnitude of the flux. However, we are not able to address this issue with the limited dataset presented here.

\subsection{Water vapour interference}

The amount of $\mathrm{H}_{2} \mathrm{O}$ molecules in the sampled air exceeds those of $\mathrm{NH}_{3}$ by typically three to six orders of magnitudes. The same holds for the associated fluxes. Well known and routinely corrected for is the dilution of the concentration due to increasing water vapour, the WPL correction (Webb et al., 1980). In addition, depending on the type of instrument, various complex water vapour interferences are possible. For instance, high resolution spectroscopy such as QCLAS or cavity ring down spectroscopy show a weak pressure broadening of absorption lines that especially influences small fluxes (Neftel et al., 2010; Tuzson et al., 2010). CIMS systems can suffer from large interferences associated with the ion source. In this respect, a closer analysis of the fluxes presented by Shaw et al. (1998) suggests an artefact related to the interference of water molecules. They reported $\mathrm{NH}_{3}$ emission fluxes of $145 \mu \mathrm{g} \mathrm{m}^{-2} \mathrm{~s}^{-1}$ and concentrations of $1340 \mu \mathrm{g} \mathrm{m}^{-3}$ from a field that was not under cultivation at that time. Such high fluxes and concentrations normally only exist directly after application of organic fertiliser. Even though the EC analyses were technically correct, it is easily possible that water vapour induced some of the reported fluxes.
Most probably, traces of $\mathrm{N}_{2}$ and $\mathrm{H}_{2} \mathrm{O}$ intrinsically create $\mathrm{NH}_{3}$ inside the PTR-MS ion source (Norman et al., 2007). Our laboratory investigations as well as the studies by Norman et al. $(2007,2009)$ revealed that the expected water vapour interference for the HT-CIMS was small. This is nicely illustrated by comparing the typical absolute water interference effect (Fig. 12, upper panel) with the $\mathrm{NH}_{3}$ fluxes recorded on slurry application days (Fig. 10) and one and a half week later (Fig. 12, lower panel), when much smaller exchange fluxes fluctuating around zero were observed. Figure 12 indicates no significant coupling between the fluxes of $\mathrm{NH}_{3}$ and $\mathrm{H}_{2} \mathrm{O}$. It is fully evident that the high slurry $\mathrm{NH}_{3}$ emissions cannot have been a consequence of any $\mathrm{H}_{2} \mathrm{O}$ interference. The flux correction due to the water dependent HTCIMS background signal was $2.1 \mathrm{ng} \mathrm{NH}_{3} \mathrm{~m}^{-2} \mathrm{~s}^{-1}$ at most, i.e. below the flux detection limit (see following Sect.). Correcting the raw data for the $\mathrm{H}_{2} \mathrm{O}$ interference instead of an integral correction (e.g. Neftel et al., 2010) eliminates possible interferences on the covariance peak detection of $\mathrm{NH}_{3}$ and thus facilitates the correct detection of $\mathrm{NH}_{3}$ fluxes under background exchange conditions.

\subsection{Contributions of ammonium aerosol}

Heating the sample gas to $150{ }^{\circ} \mathrm{C}$ and more will cause dissociation of semi-volatile aerosol compounds, such as ammonium-nitrate, as well as partly evaporation of nonvolatile species, such as ammonium-sulphate (conditions comparable to processes within thermodenuders, e.g. Huffman et al., 2008). Therefore, the HT-CIMS setup was most probably prone to measure the sum of the concentrations of $\mathrm{NH}_{3}$ and its semi-volatile particulate counterpart $\mathrm{NH}_{4}^{+}$ $\left(\mathrm{NH}_{\mathrm{x}}=\mathrm{NH}_{3}+\mathrm{NH}_{4}^{+}\right)$. The partitioning in ambient air and hence the importance of aerosol $\mathrm{NH}_{4}^{+}$on the $\mathrm{NH}_{3}$ measurement depends on relative humidity, temperature and the concentrations of other gaseous reaction partners (Seinfeld and Pandis, 2006). For conditions of small concentrations and fluxes the relative interference on the $\mathrm{NH}_{3}$ measurement could be significant. For the Swiss central plateau, characterised by intensive agriculture, more than enough $\mathrm{NH}_{3}$ for neutralising acidic gases is generally available (Spirig and Neftel, 2006), so that we can expect that $\mathrm{NH}_{3}$ exceeds $\mathrm{NH}_{4}^{+}$ under such circumstances. For example, in summer 2006 total aerosol $\mathrm{NH}_{4}^{+}$concentrations at the grassland site have been found to be roughly $10-30 \%$ of the gas phase $\mathrm{NH}_{3}$ content with only short episodes of higher ratios (Wolff et al., 2010a). Partial evaporation of this $\mathrm{NH}_{4}^{+}$in the inlet tube or HT-CIMS might interfere with the $\mathrm{NH}_{3}$ concentration measurement. After the spreading of slurry, however, the gaseous fraction dominates the $\mathrm{NH}_{\mathrm{x}}$ concentrations by far. Therefore, aerosol $\mathrm{NH}_{4}^{+}$does not significantly affect the $\mathrm{NH}_{3}$ concentration measurement.

Regarding the EC flux measurements, the partitioning between $\mathrm{NH}_{3}$ and $\mathrm{NH}_{4}^{+}$will affect the measured fluxes only when there are distinct $\mathrm{NH}_{4}^{+}$aerosol fluxes. Nemitz et 
Table 3. Estimated individual errors and error types potentially influencing the flux accuracy.

\begin{tabular}{lrl}
\hline & error & type \\
\hline calibration & $5 \%$ & systematic \\
peak covariance detection & $11 \%$ & random \\
$\mathrm{H}_{2} \mathrm{O}$ interference correction & $<1 \%$ random \\
high frequ. damping correction & $10 \%$ & systematic \\
$\mathrm{NH}_{4}^{+}$aerosol interference & $<1 \%$ & systematic \\
\hline flux accuracy & $16 \%$ & \\
\hline
\end{tabular}

al. (2009) evaluated fluxes of both species after ammoniumnitrate fertiliser application on grassland. They found the aerosol $\mathrm{NH}_{4}^{+}$fluxes to be orders of magnitudes smaller compared to the gaseous $\mathrm{NH}_{3}$ fluxes. $\mathrm{NH}_{3}$ emissions following slurry spreading are even larger than those after mineral fertiliser application. Hence the interference for the HT-CIMS derived $\mathrm{NH}_{3}$ flux is regarded to be negligibly small $(<1 \%)$ here.

\subsection{Flux accuracy}

The accuracy of the HT-CIMS EC flux measurements is influenced by different sources of uncertainty in the process of the flux determination. In principle, errors acting randomly and systematically should be distinguished (Moncrieff et al., 1996; Kroon et al., 2010). Table 3 summarises our estimates of the main error types and contributions.

The calibration was finally based on wet chemical impinger measurements and subsequent analysis by means of ion chromatography with an estimated accuracy of about $5 \%$. The HT-CIMS instrumental sensitivity was constant between both fertilisations with a drift of less than $1 \%$. Therefore, we assume the accuracy of the calibration to be $5 \%$.

During the slurry emissions the peak covariance detection was generally not problematic (Fig. 6). Under such circumstances the resulting mean flux precision (as defined in Sect. 2.2.3) was $11 \pm 3 \%$ of the measured fluxes.

The correction for high-frequency attenuation exhibits a stochastic source of uncertainty: the standard error of the linear regression that parameterises the damping (Fig. 8) gives an accuracy of the damping factors of about $10 \%$.

The absolute accuracy of the correction for the $\mathrm{H}_{2} \mathrm{O}$ interference on the $\mathrm{NH}_{3}$ flux (Fig. 12) has been estimated to be $<1 \mathrm{ng} \mathrm{m}^{-2} \mathrm{~s}^{-1}$. Considering the extremely small relative contribution to the fluxes during slurry spreading $(<1 \%$ ), the influence of the $\mathrm{H}_{2} \mathrm{O}$ flux on the overall accuracy of the EC $\mathrm{NH}_{3}$ assessment could be neglected.

Finally, taking these aspects into consideration, the accuracy of a single EC flux measurement during the slurry dominated $\mathrm{NH}_{3}$ emissions was estimated to be about $16 \%$ using Gaussian error propagation.

\subsection{Plausibility of measured fluxes}

The dynamics of the measured fluxes after slurry spreading can be described by a combined exponential decay in analogy to Eq. (5) with a fast time constant in the order of $30 \mathrm{~min}$ and a slower decrease with a time constant in the order of two to three hours. As the meteorological conditions and especially the wind direction were rather constant in the hours after slurry application (Fig. 9), changes in footprint contributions were of minor importance. Both, the initial fluxes as well as the temporal decrease were in the similar range as in slurry events previously investigated at the same site employing the aerodynamic gradient approach (Spirig et al., 2010). Since the applied slurry exhibited a relatively low dry matter content and consequently a rather low viscosity, highest emission fluxes are expected immediately after spreading of the slurry. Such thin slurry can easily infiltrate into the soil and adsorption of $\mathrm{NH}_{4}^{+}$on soil particles decreases emissions (Braschkat et al., 1997). Due to instrumental restrictions, Spirig et al. (2010) had to estimate the first 30 to $200 \mathrm{~min}$ of emissions after the spreading of the slurry. With the EC approach at hand, there is now the possibility to measure these fluxes with a high time resolution and to gain a more comprehensive picture of the emissions, especially of the dominating initial phase.

\section{Conclusions and outlook}

With the aim to perform EC measurements of $\mathrm{NH}_{3}$ fluxes, we have presented a modified version of the PTR-MS for $\mathrm{NH}_{3}$ detection via electron transfer reaction as described by Norman et al. (2007), optimised for fast time response. The system was altered to decrease the residence time of the sample gas, to reduce the metal fraction of interior surfaces, and to be able to run this HT-CIMS at temperatures well above $100^{\circ} \mathrm{C}$. This was accomplished by replacing the materials of the central analytical part and the inlet of the instrument with components made of inert and very heat resistive PEEK and silica-coated stainless steel. Significant advancement in instrumental time resolution for $\mathrm{NH}_{3}$ was mainly achieved by heating all parts to $180^{\circ} \mathrm{C}$ which minimised wall interactions with $\mathrm{NH}_{3}$.

Using a $23 \mathrm{~m}$ long inlet tube heated to $150^{\circ} \mathrm{C}$, it was possible to detect EC fluxes after slurry spreading and to empirically correct the raw $\mathrm{NH}_{3}$ fluxes for the system's highfrequency attenuation with the sensible heat flux serving as reference. The corrections were between $20 \%$ and $40 \%$ and turned out to be larger than those for the simultaneously measured $\mathrm{H}_{2} \mathrm{O}$ fluxes. A thorough analysis of the potential of $\mathrm{H}_{2} \mathrm{O}$ influencing the $\mathrm{NH}_{3}$ measurements revealed a negligible interference on the observed $\mathrm{NH}_{3}$ emission fluxes following fertilisations. Even under low flux conditions, the $\mathrm{H}_{2} \mathrm{O}$ interference effect remained relatively small. Another source of interference with negligible effect on the high emission 
fluxes, but of potential importance at low fluxes, is the dissociation of semi-volatile aerosol $\mathrm{NH}_{4}^{+}$inside the heated tube and instrument.

More work will be required to better characterise the behaviour of the system under low flux conditions. Essentially, it must be further investigated whether deposition fluxes can be measured with sufficient accuracy, since it is possible that the degree of high-frequency damping is inversely correlated with the magnitude of concentration changes (Ellis et al., 2010). In addition, the long-term performance of the inlet line has to be evaluated in order to quantify the impact of tube ageing on memory effects with potential alterations in delay time and high-frequency attenuation (Leuning and Judd, 1996).

A forthcoming publication will include the quantification of $\mathrm{NH}_{3}$ field emission losses after slurry spreading and compare the presented EC technique with an independently applied horizontal mass flux approach.

We are now confident that under conditions of high $\mathrm{NH}_{3}$ emission, the HT-CIMS setup provides robust EC flux measurements, which represents a substantial improvement in such investigations and will help to reduce the uncertainties associated with the quantification of agricultural $\mathrm{NH}_{3}$ emissions.

Acknowledgements. We thank the Swiss National Science Foundation for funding this project (TERMS, 200021-117686/1). In addition, the research leading to these results has received funding from the (EU) Seventh Framework Programme - (FP7/2007-2013) under grant agreement no (PIEF-GA-2008-220842) - as well as from the EU project NitroEurope (Contract 017841) that is funded under the EC 6th Framework Programme for Research and Technological Development. We are very grateful to Kerstin Zeyer and Lukas Emmenegger from the Swiss Federal Laboratories for Materials Science and Technology (EMPA) who provided the in-field calibration device. Finally, we thank Markus Jocher from our group for his constant support.

Edited by: A. Hansel

\section{References}

Ammann, C.: On the Applicability of Relaxed Eddy Accumulation and Common Methods for Measuring Trace Gas Fluxes, Zürcher Geographische Schriften, 73, Geographisches Institut ETH, Zürich, Switzerland, 229 pp., 1999.

Ammann, C., Spirig, C., Neftel, A., Steinbacher, M., Komenda, M., and Schaub, A.: Application of PTR-MS for Measurements of Biogenic VOC in a Deciduous Forest, Int. J. Mass Spectrom., 239, 87-101, 2004.

Ammann, C., Brunner, A., Spirig, C., and Neftel, A.: Technical note: Water vapour concentration and flux measurements with PTR-MS, Atmos. Chem. Phys., 6, 4643-4651, doi:10.5194/acp6-4643-2006, 2006.

Ammann, C., Flechard, C. R., Leifeld, J., Neftel, A., and Fuhrer, J.: The carbon budget of newly established temperate grassland depends on management intensity, Agr. Ecosyst. Environ., 121, 5-20, doi:10.1016/j.agee.2006.12.002, 2007.

Appl, M.: Ammonia: principles and industrial practice, WileyVCH, Weinheim, 301 pp., 1999.

Baek, B. H., Aneja, V. P., and Tong, Q. S.: Chemical coupling between ammonia, acid gases, and fine particles, Environ. Pollut., 129, 89-98, 2004.

Baldocchi, D. D., Hicks, B. B., and Meyers, T. P.: Measuring biosphere-atmosphere exchanges of biologically related gases with micrometeorological methods, Ecology, 69, 1331-1340, 1988.

Bamberger, I., Hörtnagl, L., Schnitzhofer, R., Graus, M., Ruuskanen, T. M., Müller, M., Dunkl, J., Wohlfahrt, G., and Hansel, A.: BVOC fluxes above mountain grassland, Biogeosciences, 7, 1413-1424, doi:10.5194/bg-7-1413-2010, 2010.

Benson, D. R., Markovich, A., Al-Refai, M., and Lee, S.-H.: A Chemical Ionization Mass Spectrometer for ambient measurements of Ammonia, Atmos. Meas. Tech., 3, 1075-1087, doi:10.5194/amt-3-1075-2010, 2010.

Berden, G., Peeters, R., and Meijer, G.: Cavity ring-down spectroscopy: Experimental schemes and applications, Int. Rev. Phys. Chem., 19, 565-607, 2000.

Blake, R. S., Monks, P. S., and Ellis, A. M.: Proton-Transfer Reaction Mass Spectrometry, Chem. Rev., 109, 861-896, 2009.

Braschkat, J., Mannheim, T., and Marschner, H.: Estimation of ammonia losses after application of liquid cattle manure on grassland, Z. Pflanzenernähr. Bodenk., 160, 117-123, 1997.

Brodeur, J. J., Warland, J. S., Staebler, R. M., and WagnerRiddle, C.: Technical note: Laboratory evaluation of a tunable diode laser system for eddy covariance measurements of ammonia flux, Agr. Forest Meteorol., 149, 385-391, doi:10.1016/j.agrformet.2008.08.009, 2008.

Businger, J. A. and Delany, A. C.: Chemical Sensor Resolution Required for Measuring Surface Fluxes by Three Common Micrometeorological Techniques, J. Atmos. Chem., 10, 399-410, 1990.

Cantrell, C. A.: Technical Note: Review of methods for linear leastsquares fitting of data and application to atmospheric chemistry problems, Atmos. Chem. Phys., 8, 5477-5487, doi:10.5194/acp8-5477-2008, 2008.

de Gouw, J. and Warneke, C.: Measurements of volatile organic compounds in the earth's atmosphere using proton-transferreaction mass spectrometry, Mass Spectrom. Rev., 26, 223-257, doi:10.1002/mas.20119, 2007.

Dabberdt, W. F., Lenschow, D. H., Horst, T. W., Zimmerman, P. R., Oncley, S. P., and Delany, A. C.: Atmosphere-Surface Exchange Measurements, Science, 260, 1472-1481, 1993.

Denmead, O. T.: Approaches to measuring fluxes of methane and nitrous oxide between landscapes and the atmosphere, Plant Soil, 309, 5-24, doi:10.1007/s11104-008-9599-z, 2008.

Desjardins, R. L., MacPherson, J. I., Schuepp, P. H., and Karanja, F.: An evaluation of aircraft flux measurements of $\mathrm{CO}_{2}$, water vapour and sensible heat, Bound.-Lay. Meteorol., 47, 55-69, 1989.

Edwards, G. C., Neumann, H. H., den Hartog, G., Thurtell, G. W., and Kidd, G.: Eddy correlation measurements of methane fluxes using a tunable diode laser at the Kinosheo Lake tower site during the Northern Wetlands Study (NOWES), J. Geophys. Res., 99, 1511-1517, 1994. 
Ellis, R. A., Murphy, J. G., Pattey, E., van Haarlem, R., O’Brien, J. M., and Herndon, S. C.: Characterizing a Quantum Cascade Tunable Infrared Laser Differential Absorption Spectrometer (QCTILDAS) for measurements of atmospheric ammonia, Atmos. Meas. Tech., 3, 397-406, doi:10.5194/amt-3-397-2010, 2010.

Erisman, J. W., Otjes, R., Hensen, A., Jongejan, P., van den Bulk, P., Khlystov, A., Mols, H., and Slanina, S.: Instrument development and application in studies and monitoring of ambient ammonia, Atmos. Environ., 35, 1913-1922, 2001.

Erisman, J. W., Bleeker, A., Galloway, J., and Sutton, M. S.: Reduced nitrogen in ecology and the environment, Environ. Pollut., 150, 140-149, 2007.

Erisman, J. W., Bleeker, A., Hensen, A., and Vermeulen, A.: Agricultural air quality in Europe and the future perspectives, Atmos. Environ., 42, 3209-3217, 2008.

Famulari, D., Fowler, D., Hargreaves, K., Milford, C., Nemitz, E., Sutton, M. A., and Weston, K.: Measuring eddy covariance fluxes of ammonia using tunable diode laser absorption spectroscopy, Water Air Soil Poll., 4, 151-158, 2004.

Fehsenfeld, F. C., Huey, L. G., Leibrock, E., Dissly, R., Williams, E., Ryerson, T. B., Norton, R., Sueper, D. T., and Hartsell, B.: Results of an informal intercomparison of ammonia measurement techniques, J. Geophys. Res., 107, 4812, doi:10.1029/2001JD001327, 2002.

Flechard, C. R. and Fowler, D.: Atmospheric ammonia at a moorland site, II: Long-term surface-atmosphere micrometeorological flux measurements, Q. J. Roy. Meteorol. Soc., 124, 759-791, 1998.

Flechard, C. R., Spirig, C., Neftel, A., and Ammann, C.: The annual ammonia budget of fertilised cut grassland - Part 2: Seasonal variations and compensation point modeling, Biogeosciences, 7 , 537-556, doi:10.5194/bg-7-537-2010, 2010.

Foken, T. and Wichura, B.: Tools for quality assessment of surface based flux measurements, Agr. Forest Meteorol., 78, 83105, 1996.

Fowler, D., Pilegaard, P., Sutton, M. A., Ambus, P., Raivonen, M., Duyzer, J., Simpson, D., Fagerli, H., Fuzzi, S., Schjoerring, J. K., Granier, C., Neftel, A., Isaksenm, S. A., Laj, P., Maione, M., Monks, P. S., Burkhardt, J., Daemmgen, U., Neirynck, K., Personne, E., Wichink-Kruit, R., Butterbach-Bahl, K., Flechard, C., Tuovinen, J. P., Coyle, M., Gerosa, G., Loubet, B., Altimir, N., Gruenhage, L., Ammann, C., Cieslik, S., Paoletti, E., Mikkelsen, T. N., Ro-Poulsen, H., Cellier, P., Cape, J. N., Horváth, L., Loreto, F., Niinemets, Ü., Palmer, P. I., Rinne, J., Misztal, P., Nemitz, E., Nilsson, D., Pryor, S., Gallagher, M. W., Vesala, T., Skiba, U., Brüggemann, N., Zechmeister-Boltenstern, S., Williams, J., O'Dowdap, C., Facchini, M. C., de Leeuw, G., Flossman, A., Chaumerliac, N., and Erisman, J. W.: Atmospheric composition change: Ecosystems - Atmosphere interactions, Atmos. Environ., 43, 5193-5267, 2009.

Galloway, J. N., Aber, J. D., Erisman, J. W., Seitzinger, S. P., Howarth, R. W., Cowling, E. B., and Cosby, B. J.: The nitrogen cascade, Bioscience, 53, 341-356, 2003.

Gutierrez, E.: Using satellite imagery to measure the relationship between air quality and infant mortality: an empirical study for Mexico, Popul. Environ., 31, 203-222, 2010.

Hansel, A., Jordan, A., Holzinger, R., Prazeller, P., Vogel, W., and Lindinger, W.: Proton-Transfer Reaction Mass-Spectrometry Online Trace Gas-Analysis at the ppb Level, Int. J. Mass Spec- trom., 149, 609-619, 1995.

Hensen, A., Nemitz, E., Flynn, M. J., Blatter, A., Jones, S. K., Sørensen, L. L., Hensen, B., Pryor, S. C., Jensen, B., Otjes, R. P., Cobussen, J., Loubet, B., Erisman, J. W., Gallagher, M. W., Neftel, A., and Sutton, M. A.: Inter-comparison of ammonia fluxes obtained using the Relaxed Eddy Accumulation technique, Biogeosciences, 6, 2575-2588, doi:10.5194/bg-6-2575-2009, 2009.

Hörtnagl, L., Clement, R., Graus, M., Hammerle, A., Hansel, A., and Wohlfahrt, G.: Dealing with disjunct concentration measurements in eddy covariance applications: A comparison of available approaches, Atmos. Environ, 44, 2024-2032, doi:10.1016/j.atmosenv.2010.02.042, 2010.

Huffman, J. A., Ziemann, P. J., Jayne, J. T., Worsnop, D. R., and Jimenez, J. L.: Development and Characterization of a Fast-Stepping/Scanning Thermodenuder for ChemicallyResolved Aerosol Volatility Measurements, Aerosol Sc. Tech., 42, 395-407, doi:10.1080/02786820802104981, 2008.

Ibrom, A., Dellwik, E., Flyvbjerg, H., Jensen, N. O., and Pilegaard, K.: Strong low-pass filtering effects on water vapour flux measurements with closed-path eddy covariance systems, Agr. Forest Meteorol., 147, 140-156, 2007.

IPCC: Climate Change 2007 - The Physical Science Basis. Contribution of Working Group I to the Fourth Assessment Report of the IPCC, The Intergovernmental Panel on Climate Change, Cambridge University Press, New York, ISBN 978052188009 1, 1009 pp., 2007.

Jost, C., Sprung, D., Kenntner, T., and Reiner, T.: Atmospheric pressure chemical ionization mass spectrometry for the detection of tropospheric trace gases: the influence of clustering on sensitivity and precision, Int. J. Mass Spectrom., 223, 771-782, 2003.

Kaimal, J. C. and Businger, J. A.: Case Studies of a Convective Plume and a Dust Devil, J. Appl. Meteorol., 9, 612-620, 1970.

Kaimal, J. C., Wyngaard, J. C., Izumi, Y., and Cotè, O. R.: Spectral characteristics of surface-layer turbulence, Q. J. Roy. Metorol. SOC., 98, 563-589, 1972.

Kaimal, J. C. and Finnigan, J. J.: Atmospheric boundary layer flows, Oxford University Press, Oxford, 280 pp., 1994.

Karl, T., Guenther, A., Lindinger, C., Jordan, A., Fall, R., and Lindinger, W.: Eddy covariance measurements of oxygenated volatile organic compound fluxes from crop harvesting using a redesigned proton-transfer-reaction mass spectrometer, J. Geophys. Res., 106, 157-167, 2001.

Karl, T. G., Spirig, C., Rinne, J., Stroud, C., Prevost, P., Greenberg, J., Fall, R., and Guenther, A.: Virtual disjunct eddy covariance measurements of organic compound fluxes from a subalpine forest using proton transfer reaction mass spectrometry, Atmos. Chem. Phys., 2, 279-291, doi:10.5194/acp-2-279-2002, 2002.

Karl, T., Potosnak, M., Guenther, A., Clark, D., Walker, J., Herrick, J. D., and Geron, C.: Exchange processes of volatile organic compounds above a tropical rain forest: Implications for modeling tropospheric chemistry above dense vegetation, J. Geophys Res., 109, D18306, doi:10.1029/2004JD004738, 2004.

Kroon, P. S., Hensen, A., Jonker, H. J. J., Ouwersloot, H. G., Vermeulen, A. T., and Bosveld, F. C.: Uncertainties in eddy covariance flux measurements assessed from $\mathrm{CH}_{4}$ and $\mathrm{N}_{2} \mathrm{O}$ observations, Agr. Forest Meteorol., 150, 806-816, doi:10.1016/j.agrformet.2009.08.008, 2010.

Lee, A., Schade, G. W., Holzinger, R., and Goldstein, A. H.: A comparison of new measurements of total monoterpene flux with 
improved measurements of speciated monoterpene flux, Atmos. Chem. Phys., 5, 505-513, doi:10.5194/acp-5-505-2005, 2005.

Lenschow, D. H. and Raupach, M. R.: The Attenuation of Fluctuations in Scalar Concentrations through Sampling Tubes, J. Geophys. Res., 96, 259-268, 1991.

Leuning, R. and Judd, M. J.: The relative merits of open- and closed-path analysers for measurement of eddy fluxes, Global Change Biol., 2, 241-253, 1996.

Lindinger, W., Hansel, A., and Jordan, A.: On-line monitoring of volatile organic compounds at pptv levels by means of ProtonTransfer-Reaction Mass Spectrometry (PTR-MS) Medical applicaitons, food control and environmental research, Int. J. Mass Spectrom., 173, 191-241, 1998.

Marek, R. and Straub, J.: Analysis of the evaporation coefficient and condensation coefficient of water, Int. J. Heat Mass Tran., 44, 39-53, 2001.

Massman, W. J. and Ibrom, A.: Attenuation of concentration fluctuations of water vapor and other trace gases in turbulent tube flow, Atmos. Chem. Phys., 8, 6245-6259, doi:10.5194/acp-86245-2008, 2008.

McManus, J. B., Shorter, J. H., Nelson, D. D., Zahniser, M. S., Glenn, D. E., and McGovern, R. M.: Pulsed quantum cascade laser instrument with compact design for rapid, high sensitivity measurements of trace gases in air, Appl. Phys. B, 92, 387-392, 2008.

McMillen, R. T.: An eddy correlation system with extended applicability to non-simple terrain, Bound.-Lay. Meteorol., 43, 231245, 1988.

Mikoviny, T., Kaser, L., and Wisthaler, A.: Development and characterization of a High-Temperature Proton-Transfer-Reaction Mass Spectrometer (HT-PTR-MS), Atmos. Meas. Tech., 3, 537544, doi:10.5194/amt-3-537-2010, 2010.

Milford, C., Theobald, M. R., Nemitz, E., Hargreaves, K. J., Horvath, L., Raso, J., Dämmgen, U., Neftel, A., Jones, S. K., Hensen, A., Loubet, B., Cellier, P., and Sutton, M. A.: Ammonia fluxes in relation to cutting and fertilization of an intensively managed grassland derived from an inter-comparison of gradient measurements, Biogeosciences, 6, 819-834, doi:10.5194/bg-6819-2009, 2009.

Moncrieff, J. B., Malhi, Y., and Leuning, R.: The propagation of errors in long-term measurements of land-atmosphere fluxes of carbon and water, Global Change Biol., 2, 231-240, 1996.

Mosquera, J., Hensen, A., van den Bulk, W. C. M., Vermeulen, A. T., and Erisman, J. W.: Long term $\mathrm{NH}_{3}$ flux measurements above grasslands in the Netherlands, Water Air Soil Poll., 1, 203-212, 2001.

Mukhtar, S., Rose, A., Capareda, S., Boriack, C., Lacey, R., Shaw, B., and Parnell, C.: Assessment of ammonia adsorption onto Teflon and LDPE tubing used in pollutant stream conveyance, Agricultural Engineering International: The CIGR Journal of Scientific Research and Development, BC03012, 2003.

Neftel, A., Flechard, C., Ammann, C., Conen, F., Emmenegger, L., and Zeyer, K.: Experimental assessment of $\mathrm{N}_{2} \mathrm{O}$ background fluxes in grassland systems, Tellus B, 59, 470-482, doi:10.1111/j.1600-0889.2007.00273.x, 2007.

Neftel, A., Ammann, C., Fischer, C., Spirig, C., Conen, F., Emmenegger, L., Tuzson, B., and Wahlen, S.: $\mathrm{N}_{2} \mathrm{O}$ exchange over managed grassland: Application of a quantum cascade laser spectrometer for micrometeorological flux measurements, Agr. Forest Meteorol., 150, 775-785, doi:10.1016/j.agrformet.2009.07.013, 2010.

Nemitz, E., Sutton, M. A., Wyers, G. P., and Jongejan, P. A. C.: Gas-particle interactions above a Dutch heathland: I. Surface exchange fluxes of $\mathrm{NH}_{3}, \mathrm{SO}_{2}, \mathrm{HNO}_{3}$ and $\mathrm{HCl}$, Atmos. Chem. Phys., 4, 989-1005, doi:10.5194/acp-4-989-2004, 2004a.

Nemitz, E., Sutton, M. A., Wyers, G. P., Otjes, R. P., Mennen, M. G., van Putten, E. M., and Gallagher, M. W.: Gas-particle interactions above a Dutch heathland: II. Concentrations and surface exchange fluxes of atmospheric particles, Atmos. Chem. Phys., 4, 1007-1024, doi:10.5194/acp-4-1007-2004, 2004 b.

Nemitz, E., Dorsey, J. R., Flynn, M. J., Gallagher, M. W., Hensen, A., Erisman, J.-W., Owen, S. M., Dämmgen, U., and Sutton, M. A.: Aerosol fluxes and particle growth above managed grassland, Biogeosciences, 6, 1627-1645, doi:10.5194/bg-6-16272009, 2009.

Norman, M., Hansel, A., and Wisthaler, A.: $\mathrm{O}_{2}^{+}$as reagent ion in the PTR-MS instrument: Detection of gas-phase ammonia, Int. J. Mass Spectrom., 265, 382-387, doi:10.1016/j.ijms. 2007.06.010, 2007.

Norman, M., Spirig, C., Wolff, V., Trebs, I., Flechard, C., Wisthaler, A., Schnitzhofer, R., Hansel, A., and Neftel, A.: Intercomparison of ammonia measurement techniques at an intensively managed grassland site (Oensingen, Switzerland), Atmos. Chem. Phys., 9, 2635-2645, doi:10.5194/acp-9-2635-2009, 2009.

Nowak, J. B., Huey, L. G., Russell, A. G., Tian, D., Neuman, J. A., Orsini, D., Sjostedt, S. J., Sullivan, A. P., Tanner, D. J., Weber, R. J., Nenes, A., Edgerton, E., and Fehsenfeld, F. C.: Analysis of urban gas phase ammonia measurements from the 2002 Atlanta aerosol nucleation and real-time characterization experiment (ANARChE), J. Geophys. Res., 111, D17308, doi:10.1029/2006JD007113, 2006.

Oncley, S. P.: Flux Parameterisation Techniques in the Atmospheric Surface Layer, $\mathrm{PhD}$ thesis, Univ. of California, Irvine, 202 pp., 1989.

Ortega, I. K., Kurtén, T., Vehkamäki, H., and Kulmala, M.: The role of ammonia in sulfuric acid ion induced nucleation, Atmos. Chem. Phys., 8, 2859-2867, doi:10.5194/acp-8-2859-2008, 2008.

Parrish, D. D. and Fehsenfeld, F. C.: Methods for gas-phase measurements of ozone, ozone precursors and aerosol precursors, Atmos. Environ., 34, 1921-1957, 2000.

Pope, C. A., Burnett, R. T., Thun, M. J., Calle, E. E., Krewski, D., Ito, K., and Thurston, G. D.: Lung cancer, cardiopulmonary mortality, and long-term exposure to fine particulate air pollution, Jama-J. Am. Med. Assoc., 287, 1132-1141, 2002.

Reidy, B., Rhimb, B., and Menzi, H.: A new Swiss inventory of ammonia emissions from agriculture based on a survey on farm and manure management and farm-specific model calculations, Atmos. Environ., 42, 3266-3276, 2008.

Rinne, H. J. I., Guenther, A., Warneke, C., de Gouw, J. A., and Luxembourg, S. L.: Disjunct eddy covariance technique for trace gas flux measurements, Geophys. Res. Lett., 28, 3139-3142, 2001.

Schwab, J. J., Li, Y., Bae, M. S., Demerjian, K. L., Hou, J., Zhou, X., Jensen, B., and Pryor, S. C.: A Laboratory intercomparison of real-time gaseous ammonia measurement methods, Environ. Sci. Technol., 41, 8412-8419, 2007.

Seinfeld, J. H. and Pandis, S. N.: Atmospheric Chemistry and Physics, John Wiley \& Sons, Inc., New Jersey, 2nd edition, 
1203 pp., 2006.

Shah, S. B., Grabow, G. L., and Westerman, P. W.: Ammonia adsorption in five types of flexible tubing materials, Appl. Eng. Agric., 22, 919-923, 2006.

Shaw, W. J., Spicer, C. W., and Kenny, D. W.: Eddy correlation fluxes of trace gases using a tandem mass spectrometer, Atmos. Environ., 32, 2887-2898, 1998.

Shindell, D. T., Faluvegi, G., Koch, D. M., Schmidt, G. A., Unger, N., and Bauer, S. E.: Improved Attribution of Climate Forcing to Emissions, Science, 326, 716-718, 2009.

Smith, J. N., Moore, K. F., Eisele, F. L., Voisin, D., Ghimire, A. K., Sakuri, H., and McMurry, P. H.: Chemical composition of atmospheric nanoparticles during nucleation in Atlanta, J. Geophys. Res., 110, D22S03, doi:10.1029/2005JD005912, 2005.

Španěl, P. and Smith, D.: Selected ion flow tube studies of the reactions of $\mathrm{H}_{3} \mathrm{O}^{+}, \mathrm{NO}^{+}$and $\mathrm{O}_{2}^{+}$with several amines and some other nitrogen containing compounds, Int. J. Mass Spectrom., 176, 203-211, 1998.

Spirig, C., Neftel, A., Ammann, C., Dommen, J., Grabmer, W., Thielmann, A., Schaub, A., Beauchamp, J., Wisthaler, A., and Hansel, A.: Eddy covariance flux measurements of biogenic VOCs during ECHO 2003 using proton transfer reaction mass spectrometry, Atmos. Chem. Phys., 5, 465-481, doi:10.5194/acp-5-465-2005, 2005.

Spirig, C. and Neftel, A.: Ammoniakemissionen aus der Landwirtschaft und Feinstaub, Agrarforschung 13, 392-397, 2006.

Spirig, C., Flechard, C. R., Ammann, C., and Neftel, A.: The annual ammonia budget of fertilised cut grassland - Part 1: Micrometeorological flux measurements and emissions after slurry application, Biogeosciences, 7, 521-536, doi:10.5194/bg-7-521-2010, 2010.

Sutton, M. A., Fowler, D., and Moncrieff, J. B.: The exchange of atmospheric ammonia with vegetated surfaces, 1 . Unfertilized vegetation, Q. J. Roy. Meteorol. Soc., 119, 1023-1045, 1993a.

Sutton, M. A., Pitcairn, C. E. R., and Fowler, D.: The exchange of ammonia between the atmosphere and plant communities, Adv. Ecol. Res., 24, 301-393, 1993 b.

Sutton, M. A., Nemitz, E., Erisman, J. W., Beier, C., ButterbachBahl, K., Cellier, P., de Vries, W., Cotrufo, F., Skiba, U., Di Marco, C., Jones, S., Laville, P., Soussana, J. F., Loubet, B., Twigg, M., Famulari, D., Whitehead, J., Gallagher, M. W., Neftel, A., Flechard, C. R., Herrmann, B., Calanca, P. L., Schjoerring, J. K., Daemmgen, U., Horvath, L., Tang, Y. S., Emmett, B. A., Tietema, A., Peñuelas, J., Kesik, M., Brueggemann, N., Pilegaard, K., Vesala, T., Campbell, C. L., Olesen, J. E., Dragosits, U., Theobald, M. R., Levy, P., Mobbs, D. C., Milne, R., Viovy, N., Vuichard, N., Smith, J. U., Smith, P., Bergamaschi, P., Fowler, D., and Reis, S.: Challenges in quantifying biosphereatmosphere exchange of nitrogen species, Environ. Pollut., 150, 125-139, 2007.
Sutton, M. A., Erisman, J. W., Dentener, F., and Möller, D.: Ammonia in the environment: From ancient times to the present, Environ. Pollut., 156, 583-604, 2008.

Tuzson, B., Hiller, R. V., Zeyer, K., Eugster, W., Neftel, A., Ammann, C., and Emmenegger, L.: Field intercomparison of two optical analyzers for $\mathrm{CH}_{4}$ eddy covariance flux measurements, Atmos. Meas. Tech. Discuss., 3, 2961-2993, doi:10.5194/amtd3-2961-2010, 2010.

von Bobrutzki, K., Braban, C. F., Famulari, D., Jones, S. K., Blackall, T., Smith, T. E. L., Blom, M., Coe, H., Gallagher, M., Ghalaieny, M., McGillen, M. R., Percival, C. J., Whitehead, J. D., Ellis, R., Murphy, J., Mohacsi, A., Pogany, A., Junninen, H., Rantanen, S., Sutton, M. A., and Nemitz, E.: Field inter-comparison of eleven atmospheric ammonia measurement techniques, Atmos. Meas. Tech., 3, 91-112, doi:10.5194/amt-3-91-2010, 2010.

Webb, E. K., Pearman, G. I., and Leuning, R.: Correction of flux measurements for density effects due to heat and water vapour transfer, Q. J. Roy. Meteorol. Soc., 106, 85-100, 1980.

Whitehead, J. D., Twigg, M., Famulari, D., Nemitz, E., Sutton, M. A., Gallagher, M. W., and Fowler, D.: Evaluation of laser absorption spectroscopic techniques for eddy covariance flux measurements of ammonia, Environ. Sci. Technol., 42, 2041-2046, doi:10.1021/es071596u, 2008.

Wichink Kruit, R. J., van Pul, W. A. J., Otjes, R. P., Hofschreuder, P., Jacobs, A. F. G., and Holtslag, A. A. M.: Ammonia fluxes and derived canopy compensation points over non-fertilized agricultural grassland in The Netherlands using the new gradient ammonia - high accuracy - monitor (GRAHAM), Atmos. Environ., 41, 1275-1287, doi:10.1016/j.atmosenv.2006.09.039, 2007.

Wienhold, F. G., Frahm, H., and Harris, G. W.: Measurements of $\mathrm{N}_{2} \mathrm{O}$ fluxes from fertilized grassland using a fast-response tunable diode-laser spectrometer, J. Geophys. Res., 99, 1655716567, 1994.

Wolff, V., Trebs, I., Ammann, C., and Meixner, F. X.: Aerodynamic gradient measurements of the $\mathrm{NH}_{3}-\mathrm{HNO}_{3}-\mathrm{NH}_{4} \mathrm{NO}_{3}$ triad using a wet chemical instrument: an analysis of precision requirements and flux errors, Atmos. Meas. Tech., 3, 187-208, doi:10.5194/amt-3-187-2010, 2010a.

Wolff, V., Trebs, I., Foken, T., and Meixner, F. X.: Exchange of reactive nitrogen compounds: concentrations and fluxes of total ammonium and total nitrate above a spruce canopy, Biogeosciences, 7, 1729-1744, doi:10.5194/bg-7-1729-2010, 2010 b.

Yokelson, R. J., Karl, T., Artaxo, P., Blake, D. R., Christian, T. J., Griffith, D. W. T., Guenther, A., and Hao, W. M.: The Tropical Forest and Fire Emissions Experiment: overview and airborne fire emission factor measurements, Atmos. Chem. Phys., 7, 5175-5196, doi:10.5194/acp-7-5175-2007, 2007. 